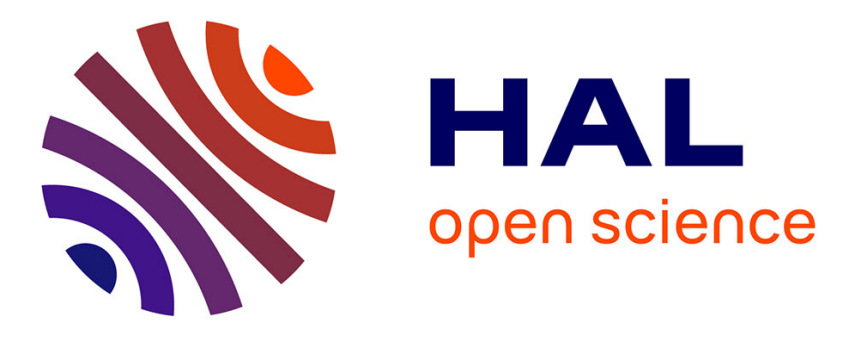

\title{
Nitrogen isotopic evolution of carbonaceous matter during metamorphism: Methodology and preliminary results
}

Magali Ader, Pierre Cartigny, Jean-Paul Boudou, Jae-Ho Oh, Eddy Petit, Marc Javoy

\section{To cite this version:}

Magali Ader, Pierre Cartigny, Jean-Paul Boudou, Jae-Ho Oh, Eddy Petit, et al.. Nitrogen isotopic evolution of carbonaceous matter during metamorphism: Methodology and preliminary results. Chemical Geology, 2006, 323 (3-4), pp.152-169. 10.1016/j.chemgeo.2006.02.019 . bioemco-00138268

\section{HAL Id: bioemco-00138268 \\ https://hal-bioemco.ccsd.cnrs.fr/bioemco-00138268}

Submitted on 22 Jun 2007

HAL is a multi-disciplinary open access archive for the deposit and dissemination of scientific research documents, whether they are published or not. The documents may come from teaching and research institutions in France or abroad, or from public or private research centers.
L'archive ouverte pluridisciplinaire HAL, est destinée au dépôt et à la diffusion de documents scientifiques de niveau recherche, publiés ou non, émanant des établissements d'enseignement et de recherche français ou étrangers, des laboratoires publics ou privés. 


\title{
Nitrogen isotopic evolution of carbonaceous matter during metamorphism: Methodology and preliminary results
}

\author{
Magali Ader ${ }^{\mathrm{a}, *}$, Pierre Cartigny ${ }^{\mathrm{a}}$, Jean-Paul Boudou ${ }^{\mathrm{b}}$, Jae-Ho Oh ${ }^{\mathrm{c}}$, \\ Eddy Petit a, , Marc Javoy ${ }^{a}$ \\ a Equipe de physico-chimie desfluides géologiques, Institut de Physique du Globe de Paris, 2 Place Jussieu, tour 54-64 1er \\ étage, 75251 Paris Cedex 05, France \\ ${ }^{\mathrm{b}}$ Laboratoire BioEMCo - UMR 7618, Case 120, Université Pierre et Marie Curie, 4, Place Jussieu, 75252 Paris Cedex 05, \\ France \\ c Korea Institute of Geoscience and Mineral Resources (KIGAM), 30 Gajeong-dong, Yuseong-gu, Daejeon, 305-350, Korea \\ ${ }^{\mathrm{d}}$ Institut Européen des Membranes de Montpellier, CC 047 Place Eugène Bataillon, 300 Avenue du, Professeur Emile \\ JEANBRAU, 34095 Montpellier Cedex 05, France
}

Abstract

Nitrogen content and isotopic composition of carbonaceous-rich metasediments were determined by online and sealed-tube combustion using ultra-high vacuum line and static mass spectrometer adapted to analyse nitrogen nanomoles. Accurate measurements showed that nitrogen amount released by on-line combustion technique was underestimated to various extents. As a result, the nitrogen isotopic composition was not correctly determined. In contrast, sealed-tube combustion appeared to yield the most reproducible and accurate measurements, except for nitrogen depleted carbonaceous matter (semi-graphite to graphite transition) containing less than around $60 \mathrm{ppm}$ of nitrogen, which were contaminated during their extraction from the rock. In view of that, a preliminary sealed-tube investigation of the organic nitrogen content and isotopic composition in a homogenous series of low-grade metasediments was undertaken: in spite of an important nitrogen loss, the carbonaceous matter nitrogen isotopic composition remains about the same during the meta-anthracite and semi-graphitisation stages. Inferences on the process of organic nitrogen mineralization during carbonaceous matter metamorphism can be drawn and several paleo-biogeochemical implications envisaged.

Keywords: Nitrogen isotopes; Metamorphism; Kerogen; Carbonaceous matter; Graphite

* Corresponding author. Tel.: +33 1442760 90; fax: +33 1442728 30; E-mail address: ader@ipgp.jussieu.fr (M. Ader).

\section{Introduction}

Analysis of nitrogen content and isotopic composition of sedimentary organic matter (atomic N / C ratio higher than 2\%) are usually performed on bulk samples using $\mathrm{C}-\mathrm{H}-\mathrm{N}$ elemental analysis or sealed-tube combustion, neglecting the associated fixed ammonium or assuming that its $\delta^{15} \mathrm{~N}$ is similar to that of the organic nitrogen. Numerous bulk sample $\delta^{15} \mathrm{~N}$ data (taken as estimates for organic matter $\delta^{15} \mathrm{~N}$ ) have thus been published, improving our understanding of the past and present nitrogen cycles in the oceans or lakes and their relations with trophic structures and/or climate (e.g. Rau et al., 1987; Talbot and Johannesseen, 1992; Altabet and Francois, 1994; Altabet et al., 1995; Caplan et al., 1996; Holmes 
et al., 1997; Schubert and Calvert, 2001; Altabet et al., 2002; Ganeshram et al., 2002). However, with kerogen maturation and following carbonaceous matter (CM) metamorphism, a significant proportion of the organic nitrogen is converted into ammonium substituting for potassium in K-bearing minerals, such as clays, micas, K-feldspar, etc. (Juster et al., 1987; Daniels and Altaner, 1990, 1993; Sucha et al., 1994). $8^{15} \mathrm{~N}$ of this neo-formed mineral nitrogen can be different from its organic source (Williams et al., 1995; Ader et al., 1998b), so that organic nitrogen $8{ }^{15} \mathrm{~N}$ measurements should be performed on isolated carbonaceous matter and mineral ones on mineral separates (e.g. Teagle et al., 2005). Due to the time-consuming $\mathrm{HCl} / \mathrm{HF}$ attack necessary for this isolation step, and to the difficult $6{ }^{15} \mathrm{~N}$ determination for samples with low atomic $\mathrm{N} / \mathrm{C}$ ratios, only few data on organic nitrogen content and $8{ }^{15} \mathrm{~N}$ are available in metamorphic rocks (Ader et al., 1998a; Beaumont and Robert, 1999; Jia and Kerrich, 2004a,b; Ueno et al., 2004; Van Zuilen et al., 2005) as well as in extraterrestrial material (e.g. Kerridge et al., 1987; Sephton et al., 2003).

These data were obtained using different methods such as: sealed-tube combustion (Ader et al., 1998a; Beaumont and Robert, 1999), CHN analyser (Ueno et al., 2004; Jia and Kerrich, 2004b) or on-line steppedpyrolysis/combustion (Van Zuilen et al., 2005). So far, these methods have not been compared to each other for carbonaceous-rich metasediments. Consequently, different datasets cannot be compared either, while their use as a paleoenvironment reconstruction tool for the Archean period (Beaumont and Robert, 1999; Jia and Kerrich, 2004b; Ueno et al., 2004), relies on the assumption that organic nitrogen $8^{15} \mathrm{~N}$ do not change with increasing maturation. Partial studies performed on homogenous series of sedimentary organic matter from terrestrial plant matter that is lacking in lipids or waxy matter, showed that mean organic nitrogen $8^{15} \mathrm{~N}$ does not change until the oil window (Boudou et al., 1984) and during anchi and epi-metamorphism (Ader et al., 1998a), where the mean organic atomic $\mathrm{N} / \mathrm{C}$ ratio decreases from $2 \%$ in anthracite to $0.5 \%$ in meta-anthracite (Volkova and Bogdanova, 1989; Daniels and Altaner, 1990, 1993; Ader et al., 1998a). This organic nitrogen $8{ }^{15} \mathrm{~N}$ steadiness still needs to be established for higher metamorphic grades (green-schist and amphibolite grades) corresponding to the meta-anthracite and semi-graphite stages, i.e. the ultimate stages of $\mathrm{H}, \mathrm{O}, \mathrm{N}, \mathrm{S}$ removal from the carbonaceous matter, which not necessarily lead to long range crystalline ordering and well crystallized graphite (graphite). For such intermediate to high metamorphic grades, ammonium $6{ }^{15} \mathrm{~N}$ has been proposed as a tracer for the reconstruction of nitrogen cycle in the Archean(Boyd, 2001a,b; Jia and Kerrich, 2004a;
Papineau et al., 2005). However, because metamorphic thermal devolatilization progressively enriches the residual fixed ammonium in ${ }^{15} \mathrm{~N}$ (Haendel et al., 1986; Bebout and Fogel, 1992; Mingram and Bräuer, 2001), ammonium $6{ }^{15} \mathrm{~N}$ in metamorphic rocks can only be considered as a higher estimate of the initial $6{ }^{15} \mathrm{~N}$. For all these reasons, measuring the change in carbonaceous matter $8{ }_{15} \mathrm{~N}$ during increasing metamorphism represents a necessary contribution towards modelling the nitrogen transfer in the crust, as well as deciphering the evolution of the biosphere during the Archean period.

To achieve this goal, the present paper (1) provides a thorough comparison of sealed-tube combustion to one type of on-line combustion method, (2) addresses the problem of nitrogen contamination during carbonaceous matter extraction, and (3) presents preliminary data on nitrogen content and isotopic composition of carbonaceous matter in a meta-anthracite to graphite sequence.

\section{Geological background and material}

\subsection{Terminology}

In this paper we use the term of kerogen in its genetic meaning: organic matter insoluble in common organic solvents and in boiling $\mathrm{HF} / \mathrm{HCl}$, and able to generate and expel hydrocarbons if its level of thermal maturity was higher. In the case of metamorphism, this simple analytical definition would lead to consider all insoluble allotropic carbon forms as kerogen. It is the reason why, beyond the point of convergence of the kerogen paths, or maceral path in the case of coal, in a $\mathrm{H} / \mathrm{C}$ versus $\mathrm{O} / \mathrm{C}$ van Krevelen diagram (Durand and Monin, 1980), one should no more speak of kerogen but of carbonaceous matter (CM). We will use this term to design solid HF/ $\mathrm{HCl}$ extractable amorphous carbonaceous material (a solid high in content of the element carbon without long range crystalline order and structurally in a non-graphitic state), semi-graphite or graphite-d1 and graphite. Semigraphite is characterised by a relatively intense 002 peak at about 3.35-3.36 $\AA$, which however, is noticeably broadened and more or less skewed toward lower angles. The 002 peak spacing is more or less large but the reflections other than 002 are absent. Graphite is characterised by $3.35-3.36 \AA$ as well as other considerably weaker reflections at higher angles (e.g., 100, 101, 004, Landis, 1971; Kwieciñska and Petersen, 2004). In the case of coal (rock containing more than $40 \%$ of carbon, whatever the kerogen or maceral path), the metaanthracite rank, within the ASTM D388-05 standard anthracite rank, starts for a volatile matter content equal 
or less than $2 \%$ dry ash free. Up to a value of vitrinite $\mathrm{R}_{\max }$ of $5 \%$, the beginning of graphitization causes a decrease in Rmin. This stage of thermal metamorphism defines the transition from anthracite to meta-anthracite stage (ASTM classification), which ends at ${ }^{\mathrm{R}}{ }_{\max }$ of $6.5 \%$ (Kwieciñska and Petersen, 2004).

\subsection{Sample set}

The sample set (Table 1) is composed of (1) hard solid bitumen, resulting from a primary algal phase (representative of type I or type II kerogen) followed by a generation of bitumen in the course of thermal evolution of

Table 1

Samples presentation: maturation degree, provider name, sampling location and details on the carbonaceous matter type, origin, or metamorphic history are given when available (Oh et al., 1991; Jehlička, 1994; Jehlička et al., 1997; Zheng and Chen, 1995; Zheng et al., 1996)

\begin{tabular}{|c|c|c|c|c|c|}
\hline $\begin{array}{l}\text { Sample } \\
\text { reference }\end{array}$ & CM type/rank & $\begin{array}{l}\text { Maturation } \\
\text { indicator }\end{array}$ & Provider & Sampling location & $\begin{array}{l}\text { CM source, } \\
\text { metamorphism type }\end{array}$ \\
\hline SB-11 & Solid bitumen & $\mathrm{R}_{\text {m a } x}=6.4 \%$ & J. Jehlička & Mitov, Bohemian Massif & Bitumen, contact metamorphism \\
\hline SB-7 & Solid bitumen & & J. Jehlička & Mitov, Bohemian Massif & Bitumen, contact metamorphism \\
\hline SB-21 & Meta-anthracite & & J. Jehlička & Slovaquie, Bohemian Massif & $\begin{array}{l}\text { Disseminated kerogen in Mesozoic } \\
\text { schists }\end{array}$ \\
\hline SB-16 & Meta-anthracite & $\mathrm{R}_{\text {max }}=5.7 \%$ & J. Jehlička & Zbecno, Bohemian Massif & Disseminated kerogen in Proterozoic \\
\hline PIES-6770 & Meta-anthracite & $\mathrm{R}_{\text {max }}=7.1 \%$ & A. V.R. & $\begin{array}{l}\text { North Germany, Bramsche } \\
\text { Massif }\end{array}$ & Coal, batholith contact metamorphism \\
\hline GP HT-HP & Semi-graphite & & J. Levine & $\begin{array}{l}\text { Appalachian foreland, } \\
\text { Pennsylvania }\end{array}$ & HP-HT experiment ( ) \\
\hline SG-K & Semi-graphite & & J. Kuili & Western Beijing & Coal, contact metamorphism \\
\hline GL 1-3 & Semi-graphite & & Z. Zheng & Luntang area, Hunan province & Coal, granite contact metamorphism \\
\hline GL 2-3 & $\begin{array}{l}\text { Not well cryst. } \\
\text { graphite }\end{array}$ & & Z. Zheng & Luntang area, Hunan province & Coal, granite contact metamorphism \\
\hline GL 4-3 & $\begin{array}{l}\text { Not well cryst. } \\
\text { graphite }\end{array}$ & & Z. Zheng & Luntang area, Hunan province & Coal, granite contact metamorphism \\
\hline \multirow[t]{2}{*}{ GL 3-3 } & $\begin{array}{l}\text { Not well cryst. } \\
\text { graphite }\end{array}$ & & Z. Zheng & Luntang area, Hunan province & Coal, granite contact metamorphism \\
\hline & & $\mathrm{XRD}_{\mathrm{d} 002}(\AA)$ & & & \\
\hline DS2 & Meta-anthracite & 3.58 & J.-H. Oh & Daeseong coal mine, Korea & Coal, regional metamorphism \\
\hline DS1 & Meta-anthracite & 3.52 & J.-H. Oh & Daeseong coal mine, Korea & Coal, regional metamorphism \\
\hline BU1 & Meta-anthracite & 3.52 & J.-H. Oh & Boeun coal mine, Korea & Coal, regional metamorphism \\
\hline DS5 & Semi-graphite & $3.37-3.38$ & J.-H. Oh & Daeseong coal mine, Korea & Coal, dyke contact metamorphism \\
\hline DS6 & Semi-graphite & $3.37-3.38$ & J.-H. Oh & Daeseong coal mine, Korea & Coal, dyke contact metamorphism \\
\hline DS7 & Semi-graphite & $3.37-3.38$ & J.-H. Oh & Daeseong coal mine, Korea & Coal, dyke contact metamorphism \\
\hline DS4 & Semi-graphite & $3.37-3.38$ & J.-H. Oh & Daeseong coal mine, Korea & Coal, dyke contact metamorphism \\
\hline BM6 & $\begin{array}{l}\text { Not well cryst. } \\
\text { graphite }\end{array}$ & 3.364 & J.-H. Oh & Bongmyeong coal mine, Korea & Coal, granite contact metamorphism \\
\hline BM21 & $\begin{array}{l}\text { Not well cryst. } \\
\text { graphite }\end{array}$ & 3.365 & J.-H. Oh & Bongmyeong coal mine, Korea & Coal, granite contact metamorphism \\
\hline BM44 & $\begin{array}{l}\text { Not well cryst. } \\
\text { graphite }\end{array}$ & 3.360 & J.-H. Oh & Bongmyeong coal mine, Korea & Coal, granite contact metamorphism \\
\hline FGR 218-1 & Graphite & & Timcal & Nei Mongol Wuchuan, China & Kerogen \\
\hline FGR 240-2 & Graphite & & Timcal & Kropfmühl, Passau, Germany & Kerogen \\
\hline FGR 132-2 & Graphite & & Timcal & Itapecerica, Brasil & Kerogen \\
\hline FGR 227-2 & Graphite & & Timcal & Itapecerica, Brasil & Kerogen \\
\hline FRG 227-1 & Graphite & & Timcal & Pedra Azul, Brasil & Kerogen \\
\hline FGR 2984 & Graphite & & Timcal & Stratmin, Lac des îles, Quebec & Disseminated kerogen in marble \\
\hline FGR 169-8 & Graphite & & Timcal & Stratmin, Lac des îles, Quebec & Disseminated kerogen in marble \\
\hline FGR 241-I & Graphite & & Timcal & $\begin{array}{l}\text { Kahatagaha, Kurunegala, Sri } \\
\text { Lanka }\end{array}$ & Vein graphite \\
\hline FRG 279-2 & Graphite & & Timcal & Wuchan, China & Kerogen \\
\hline FRG 130-I & Graphite & & Timcal & Shandong Nanshu, China & Kerogen \\
\hline
\end{tabular}

WM-GP-M8-1 anthracite (Hryckowian et al., 1967; Levine and Davis, 1989) treated at $3.5 \mathrm{GPa}, 750{ }^{\circ} \mathrm{C}, 24 \mathrm{~h}$ in gold cell (Boudou et al., 1997). Ref SB 7-21: Jan Jehlička, Department of Geochemistry, Charles University Albertov 6, Prague 2, 12843 Czech Republic. PIES: Angelika ViethRedemannn Geologishes Landesamt NRW De-Greiff-Str. 195, 47803 Krefeld Deutschland. SG-K: Jin Kuili, Graduate School, China University of Mining and Technology, 13 Xuieyuan Road, Beijing 100083, China. GL: Zhe Zheng, Peking University, Department of Geology, Beijing, 100871 China. DS, BM: Jae-Ho Oh, Korea Institute of Geoscience and Mineral Resources (KIGAM), 30 Gajeong-dong, Yuseong-gu, Daejeon 305-350, Korea. FGR: Francis Fischer, TIMCAL — Graphite and Technologies, CH - 5643 Sins, Switzerland. 
the sedimentary series, and ending by their high-temperature transformation related to a basalt extrusion, (2) meta-anthracite, semi-graphite and not well crystallized graphite samples derived from vitrinite rich-coals representative of type III kerogen (sedimentary organic matter derived from terrestrial plant matter that is lacking in lipids or waxy matter) (3) $\mathrm{HF} / \mathrm{HCl}$ purified graphites resulting from regional or contact metamorphic transformation of carbonaceous matter dispersed in a rock matrix.

Meta-anthracites are here the less mature samples with an atomic $\mathrm{N} / \mathrm{C}$ ratio inferior to $5 \times 10^{-3}$ (Volkova and Bogdanova, 1989; Ader et al., 1998a). At the top of the maturation scale, graphite can be considered as pure carbon supposedly containing only nitrogen traces. Highly carbonized hard solid bitumens from basaltic rocks, which cross-cut a black shale formation of Upper Proterozoic age in central and western part of the Bohemian Massif, Czech Republic, are characterized by a low atomic $\mathrm{H} / \mathrm{C}$ ratio of about 0.1 . They differ from dispersed kerogens isolated from regionally metamorphosed black shales of the same primary sedimentary basin (Jehlicka, 1994; Jehlicka et al., 1997, 2003).

In a first part, sealed-tube and on-line combustion methods for isotopic ratio determination of nitrogen are tested and compared between each other for a set of carbonaceous-rich metasedimentary rocks of variable types and origins.

In a second part, the impact of graphitization on both $\mathrm{N}$-content and ${ }_{6} 15_{\mathrm{N}}$ of the kerogen extracted from organicrich metasedimentary rocks is investigated using a subset of 14 samples, selected in coal bodies from three different formations and affected to various degrees by regional and contact metamorphism. Carbonaceous matter from vitrinite-rich coals can be considered as representative of the disseminated sedimentary organic of the same type III kerogen (Durand and Monin, 1980): the most important form of kerogen which gives rise to large carbonaceous matter and graphite deposits in the earth crust. According to reference information already available, kerogen ${ }_{61} 15_{\mathrm{N}}$ of coal of various age and location varies within a relatively narrow range of $-3.4 \%$ o to $+5.5 \%$ o (Parwel et al., 1957; Boudou et al., 1984; Rigby and Batts, 1986; Whiticar, 1996; Ader et al., 1998a). This initial range of $8^{15} \mathrm{~N}$ is narrower than the range of ${ }_{615 \mathrm{~N}}$ in marine sediments $(-2.7 \%$ o up to $+12 \%$ ) (Peters et al., 1978; Rau et al., 1987), so that the ${ }_{6}{ }_{15} \mathrm{~N}$ change along the kerogen maturation paths (from sedimentary deposition to the metamorphism onset) can be more straightforwardly determined with this type of kerogen, though it would be useful to investigate the different kerogen (I and II) maturation paths in this respect.

At first sight, vitrinite-rich coal generated from higher plants that started to evolve in the Phanerozoic, should not be appropriate to study Archean sedimentary organic matter predominantly derived from marine unicellular organisms (more like type I and/or type II kerogen) and it should be stated that coal may not represent the $\mathrm{N}$-systematics of Archean sedimentary kerogen. In fact, the rock samples used in this work have been chosen because they are very rich in carbon and purer carbonaceous matter can be extracted from them as a result. This carbonaceous matter contains more than $97 \%$ of carbon. Assuming that it contains some residual heteroelements, its atomic $\mathrm{H} / \mathrm{C}$ ratio would be lower than 0.37: a value located much below the ordinary type I, II, II-S, III kerogen or maceral paths plotted in a $\mathrm{H} / \mathrm{C}$ versus $\mathrm{O} / \mathrm{C}$ van Krevelen's diagram (Durand and Monin, 1980) where one can easily predict the possible average molecular structure of this hydrogen depleted solid as van Krevelen himself did (Van Krevelen, 1961, 1990). In this post-kerogen region, one can no more speak of kerogen but of carbonaceous matter (including kerogen residue and solid bitumen). Whatever the initial kerogen source, the only imaginable model for a carbonaceous matter resulting from long-term thermal reaction and containing more than $97 \%$ of carbon, is a solid made of a combination of basic structural units (BSU), along a well-known structural and textural model developed by Oberlin and co-workers (Bonijoly et al., 1982; Oberlin, 1984; Beyssac et al., 2002), where nitrogen is involved in polyaromatic systems (pyridinic and cyclazine or quaternary type nitrogen).

Among the 14 samples specifically selected for studying the impact of graphitization on both carbonaceous N-content and $6{ }^{15} \mathrm{~N}, 6$ samples (DS series) belong to the Permian anthracite bodies of the Sadong formation, which underwent several deformations, with thrusting (Kim, 1986) and low-grade (chlorite grade) regional metamorphism. Powder XRD analysis showed that, apart from quartz, DS and BM6 samples contain muscovite and illite as major mineral species. DS1 and DS2 contain chlorite, in addition to muscovite and illite. These phyllosilicates, which account for an important part of the total mineral matter are present in inclusions in the carbonaceous matrix and may contain some ammonium. Samples DS4 to DS7 were collected in the Daeseong mine within $1.5 \mathrm{~m}$ of a Cretaceous porphyritic dyke (5 m thick; intrusion temperature: about $700{ }^{\circ} \mathrm{C}$; and intrusion pressure: a few kbar). The samples DS1 and DS2 were collected $1 \mathrm{~km}$ away from the dyke and were not affected by the contact metamorphism. One sample (BU1 sample) belongs to the Boeun $(\mathrm{Bu})$ anthracite field (South Korea, $30 \mathrm{~km}$ away from the 
Moongyeong coal basin) deposited at the same time as the Sadong formation and affected by a similar tectonic and metamorphic history. This sample is considered as an equivalent of the DS1 and DS2 samples. Three samples (BM series) were collected from a coal body in the Bongmyeong mine (Jurassic Bongmyeongri formation) within $700 \mathrm{~m}$ of the border of a granite intrusion. Contact metamorphism was developed between 2 and $5 \mathrm{kbar}$, up to a distance of several kilometres from the granite intrusion. The maturation degree of DS and BM samples $\mathrm{CM}$ was evaluated using the graphitic interlayer spacing $\mathrm{d}_{002}$ calculated from X-ray diffraction, and TEM observation (Oh et al., 1991). Based on those data, the samples are sorted by increasing maturity order in Table 1 . The remaining four samples (GL series) were collected from the Lutang graphite deposit in Hunan province and the Panshi graphite deposit in Jiling province in China. The Lutang deposit was formed as a result of regional metamorphism of early Paelozoic (Upper Permian) coalbearing formation. They were graphitized in response to the thermal contact metamorphism caused by the intrusion of Indosinian Qitianling granite. The major rock types in the deposit are dark green slate and hornfels. In addition to graphitization, the country rocks of the coal bodies have also been subjected to silicification and andalucitization. The content of andalucite in andalucite hornstone may reach $10 \%$ to $35 \%$. Previous studies reported the microstructure, reflectivity (Zheng et al.,
1996), and the Raman spectra (Zheng and Chen, 1995) of the graphitized coal bodies from the Upper Permian Leping group but the data are not available for the GL samples studied here. GL reference numbers GL4-3, GL3-3, GL2-3 and GL 1-3 are arranged in order of an increasing distance from the intrusion body.

There is still a lot of debate about the relative importance of pressure-temperature profiles for coal/kerogen graphite formation (e.g. Landis, 1971; Buseck and BoJun,1985; Beyssac et al., 2002). In the present work, low pressure and high temperature (LP-HT) contact metamorphism series were preferred to high pressure-low temperature (HP-LT) regional metamorphic series, which involve high degree of strain, because contact metamorphism offers more homogeneous series to follow the metamorphic transformation from a single carbonaceous matter source.

\section{Methods}

The major analytical problem associated with $\mathrm{N}$ content and $\delta^{15} \mathrm{~N}$ measurements of carbonaceous-rich metamorphic rocks (characterised by low atomic N / C ratio b5 $\times 10^{-3}$ ) comes from the large amounts of $\mathrm{CO}_{2}$ produced during combustion and from the possible production of associated traces of carbon monoxide. Moreover, high partial pressure of $\mathrm{CO}_{2}$ prevents an efficient reduction of trace amounts of $\mathrm{NO}_{x}$ into $\mathrm{N}_{2}$ (Boyd

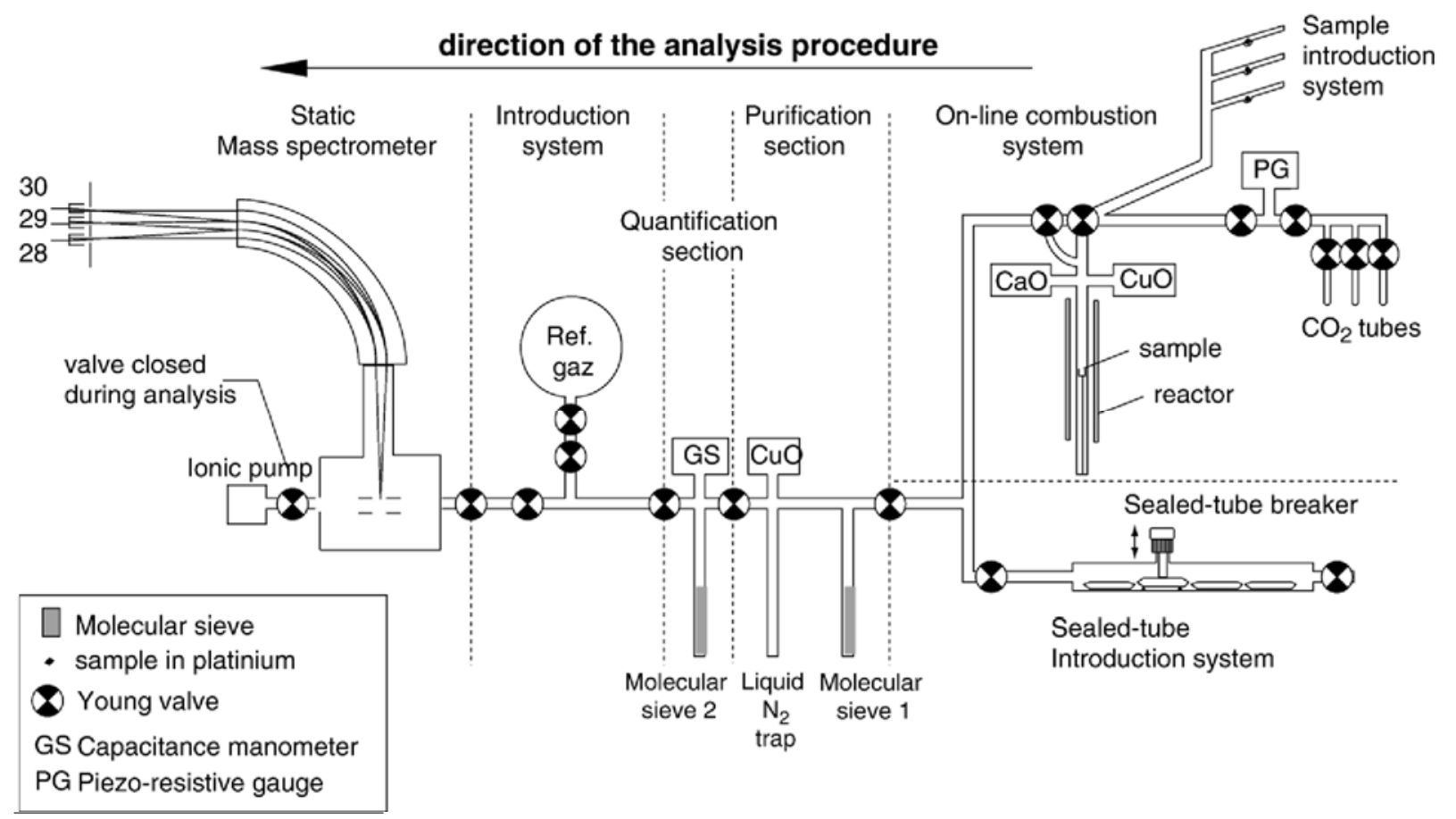

Fig. 1. Schematic representation of the ultra high-vacuum line. 
et al., 1994). This problem was overcome using $\mathrm{CaO}$ for both sealed-tube (Kendall and Grim, 1990; Ader et al., 1998a) and on-line combustion (Boyd et al., 1994). At $600{ }^{\circ} \mathrm{C}, \mathrm{CaO}$ reacts with $\mathrm{CO}_{2}$ to form $\mathrm{CaCO}_{3}$, lowering the partial pressure of $\mathrm{CO}_{2}$ and therefore allowing the reduction of $\mathrm{NO}_{x}$. The $8{ }^{15} \mathrm{~N}$ measurement of low nitrogen amounts requiring low blanks, the apparatus used in the present study involves a static mass-spectrometer coupled to an ultra-high vacuum line (Fig. 1) allowing $6^{15} \mathrm{~N}$ measurement with a precision of $\pm 0.5 \% \circ(2 \mathrm{Q})$ on 1 $2 \mathrm{nmol}$ of $\mathrm{N}_{2}$ gas. It has already yielded measurements of both $\mathrm{N}$-contents and $8^{15} \mathrm{~N}$ of diamonds (on-line combustion; Cartigny et al., 2001), metamorphic rocks (sealed-tube pyrolysis; Boyd, 1997; sealed-tube combustion; Busigny et al., 2003) and oceanic crustal rocks (sealed-tube combustion; Busigny et al., 2005). Although the sealed-tube and on-line combustion methods have already been described for the previous sample types, they had to be adapted for the $\mathrm{N}$ content and $6{ }_{15} \mathrm{~N}$ analyses of organic-rich metasediments.

3.1. Sample preparation and purification from modern organic contamination

Samples were ground into a fine powder $(<160 \mu \mathrm{m})$ to provide homogeneous starting material. For some of them, the carbonaceous matter (CM) was isolated using the conventional $\mathrm{HF} / \mathrm{HCl}$ kerogen preparation method (Durand and Nicaise, 1980). Between 0.5 and $3 \mathrm{mg}$ of bulk-rock and/or isolated CM powder were embedded in $3 \times 3 \mathrm{~mm}$ platinum foil $(0.02 \mathrm{~mm}$ thick $)$ previously purified by heating at $1050{ }^{\circ} \mathrm{C}$ in air. Taking the example of living bacteria atomic $\mathrm{N} / \mathrm{C}$ ratio $\left(-100^{1}\right)$, a contamination of $500 \mathrm{ppm}(\mathrm{\mu g} / \mathrm{g})$ of modern organic carbon would correspond to a contamination of $-50 \mathrm{ppm}$ of nitrogen. Therefore, when analysing trace amounts of nitrogen, any modern organic contamination must be removed. For diamonds, metamorphic rocks, oceanic crustal rocks and graphites, modern organic contamination is removed by off-line precombustion at $600{ }^{\circ} \mathrm{C}$ (Boyd et al., 1995), on-line precombustion at 575 or $450{ }^{\circ} \mathrm{C}$ (Boyd, 1997; Busigny et al., 2005) and on-line precombustion at $450{ }^{\circ} \mathrm{C}$ (Van Zuilen et al., 2005), respectively. For samples containing CM of lower maturity than graphite, such precombustion temperatures will initiate the combustion of the CM itself (Gilmour and Pillinger, 1985). In this study the samples were precombusted off-line in a muffle furnace for $15 \mathrm{~min}$ at $400{ }^{\circ} \mathrm{C}$, a procedure commonly used for destroying modern organic matter. Mass loss after the precombustion was lower than $1 \%$ and $\mathrm{N}$-content and ${ }_{6} 15_{\mathrm{N}}$ results obtained on the raw and pre-combusted semigraphitesample GL 3-1 are consistent (Table 2), demonstrating that the sample's nitrogen is not affected by the precombustion step.

\subsection{Sealed-tube combustion}

The sealed-tube combustion procedure is slightly modified from the method detailed recently by Busigny et al. (2005). Only the modifications will be presented here. The major difference lies in the amounts of $\mathrm{CaO}$ and $\mathrm{CuO}$ used in the sealed-tubes: $200 \mathrm{mg}$ of $\mathrm{CuO}$ wires and $100 \mathrm{mg}$ of $\mathrm{CaO}$ granules, instead of $120 \mathrm{mg}$ and $15 \mathrm{mg}$ respectively used by Busigny et al. (2005) for carbonaceous-poor rocks (less than $0.1 \% \mathrm{C}$ ). For carbonaceous-rich samples the amount of $\mathrm{CuO}$ (oxidant) and $\mathrm{CaO}$ have to be sufficient to allow the combustion of the carbon and the fixation of the evolved $\mathrm{CO}_{2}$ respectively. In return, no $\mathrm{Cu}$ is needed as it is formed during the combustion step from the reduction of the $\mathrm{CuO}$. Measured nitrogen blanks for this method are of $1.1 \pm$ $0.5 \mathrm{nmol} \mathrm{N}$ with a mean $8{ }^{15} \mathrm{~N}$ value of $4 \pm 6 \%$ o (1Q). The reagents being the major source of nitrogen contamination, the blanks are higher by a factor of 2 compared to the $0.6 \pm 0.3 \mathrm{nmol}$ reported by Busigny et al. (2005).

The other modification deals with the last purification step of the sealed-tube and sample. Instead of being purified at $450{ }^{\circ} \mathrm{C}$ under vacuum first and then under oxygen, the sample is degassed at $400{ }^{\circ} \mathrm{C}$ under vacuum only, to avoid the onset of combustion. Because this modification might participate in increasing the blanks, the amount of ${ }^{40} \mathrm{Ar}$ was monitored and found to be higher for samples than for blanks. Assuming that ${ }^{40} \mathrm{Ar}$ comes from atmospheric contamination the corresponding $\mathrm{N}_{2}$ contamination (i.e. the nitrogen blank) can be calculated. The nitrogen blank amount calculated by this method for the sealed-tube blank analyses corresponds to the effectively measured $1.1 \pm 0.5 \mathrm{nmol}$. In contrast, for sample analyses, the calculated blanks $(3 \pm 1.5 \mathrm{nmol}$, see Tables 3, 4 and 5) are higher but remain negligible, except for semi-graphite and graphite samples, which require a blank correction. However, these nitrogen blanks must only be considered as maximum estimates since a

Table 2

$\mathrm{N}$ content and ${ }_{61} 15_{\mathrm{N}}$ results obtained on the raw or precombusted GL 13 sample (using sealed-tube combustion)

\begin{tabular}{llll}
\hline GL 1-3: & \multicolumn{4}{c}{ Precombustion Degassing ppm $\mathrm{N}_{6}{ }_{6} 5_{\mathrm{N}} \pm 0.5 \% \circ$} \\
semi-graphite $\mathrm{T}\left({ }^{\circ} \mathrm{C}\right)$ & $\mathrm{T}\left({ }^{\circ} \mathrm{C}\right)$ & & \\
\cline { 2 - 5 } Bulk sample None & 400 & 1150 & 2.6 \\
Bulk sample 400 & 400 & 1170 & 2.4 \\
Bulk sample 400 & 400 & 1270 & 2.7
\end{tabular}

Precombustion: $15 \mathrm{~min}$ at $400^{\circ} \mathrm{C}$ in air in a furnace. 
Table 3

$\mathrm{N}$ content and ${ }_{{ }_{1} 5_{\mathrm{S}}}$ results obtained by on-line and sealed-tube combustion methods

\begin{tabular}{|c|c|c|c|c|c|c|c|c|c|c|c|c|}
\hline \multirow{2}{*}{$\begin{array}{l}\text { CM type } \\
\text { Sample } \\
\text { references }\end{array}$} & \multirow[b]{2}{*}{$\begin{array}{l}\% \mathrm{C} \\
\pm 2 \%\end{array}$} & \multirow[b]{2}{*}{$\begin{array}{l}6^{13} \mathrm{C} \\
\pm 0.1 \% \circ\end{array}$} & \multicolumn{2}{|c|}{$\begin{array}{l}\text { On-line } \\
\text { combustion }\end{array}$} & \multirow[b]{2}{*}{$\begin{array}{l}\text { ppm N } \\
\pm 4 \% \text { rel }\end{array}$} & \multirow[b]{2}{*}{$\begin{array}{l}615 \mathrm{~N} \\
\pm 0.5 \%\end{array}$} & \multicolumn{2}{|c|}{$\begin{array}{l}\text { Sealed-tube } \\
\text { combustion }\end{array}$} & \multirow[b]{2}{*}{$\begin{array}{l}\text { ppm N } \\
\pm 4 \% \text { rel }\end{array}$} & \multirow[b]{2}{*}{$\begin{array}{l}{ }_{615} \mathrm{~N} \\
\pm 0.5 \% \circ\end{array}$} & \multicolumn{2}{|c|}{$\begin{array}{l}\text { Difference } \\
\text { method }\end{array}$} \\
\hline & & & $\begin{array}{l}\text { Blk } \\
\text { nmol }\end{array}$ & Blk \% & & & $\begin{array}{l}\text { Blk } \\
\text { nmol }\end{array}$ & Blk \% & & & $\begin{array}{l}\mathrm{A} 61_{15} \mathrm{~N} \\
\pm 2 \% \mathrm{o}\end{array}$ & $\begin{array}{l}\text { AN / N } \\
\pm 7 \%\end{array}$ \\
\hline \multicolumn{13}{|l|}{ Solid bitumens } \\
\hline SB-11 & 75 & -29.7 & & & 1560 & -9.4 & & & 2095 & -4.2 & +5.2 & 25.5 \\
\hline SB-7 & 76 & -30.4 & & & 1600 & -6.7 & & & 1830 & -4.0 & +2.7 & 12.6 \\
\hline \multicolumn{13}{|l|}{ Meta-anthracites } \\
\hline PIES-6770 & 94 & -24.1 & & & 3798 & -1.1 & & & 4600 & +3.0 & & \\
\hline PIES-6770 & & & & & 3555 & -3.5 & & & 4200 & +4.3 & & \\
\hline PIES-6770 & & & & & 3922 & -3.1 & & & 4300 & +3.1 & & \\
\hline Average & & & & & $3758 \pm 187$ & $-2.57 \pm 1.29$ & & & $4367 \pm 208$ & $+3.47 \pm 0.72$ & +6.0 & 13.9 \\
\hline PIES-6770 ${ }^{\mathrm{b}}$ & & & & & & & & & $4500 \pm 300$ & $+3.45 \pm 0.15$ & & \\
\hline SB-16 & 37 & -33.4 & & & 1543 & -4.1 & & & 1875 & +1.0 & +5.1 & 17.7 \\
\hline SB-21 & 30 & -22.0 & & & 2240 & -4.0 & & & 2210 & -3.5 & & \\
\hline SB-21 & & & & & & & & & 2300 & -2.9 & & \\
\hline Average & & & & & & & & & $2255 \pm 64$ & $-3.2 \pm 0.42$ & +0.8 & 0.7 \\
\hline \multicolumn{13}{|l|}{ Semi-graphites } \\
\hline GP HT HP & 45 & -23.7 & & & 2670 & -3.9 & & & 3281 & +3.3 & & \\
\hline GP HT HP & 45 & -24.0 & & & 2580 & -1.3 & & & 3200 & +3.8 & & \\
\hline Average & & & & & $2625 \pm 64$ & $-2.60 \pm 1.84$ & & & $3241 \pm 57$ & $+3.55 \pm 0.35$ & +6.2 & 19.0 \\
\hline SG-K & 5 & -21.0 & & & 2835 & +4.7 & & & 2875 & +3.5 & & \\
\hline SG-K & & & & & 2770 & +2.0 & & & 3150 & +4.4 & & \\
\hline SG-K & & & & & 2620 & +4.4 & & & 2600 & +3.9 & & \\
\hline SG-K & & & & & 2830 & +1.5 & & & 2800 & n.d. & & \\
\hline Average & & & & & $2764 \pm 100$ & $+3.15 \pm 1.63$ & & & $2856 \pm 228$ & $+3.93 \pm 0.45$ & +0.8 & 3.2 \\
\hline GL $1-3$ & 77 & -19.3 & & & 1186 & +3.8 & 3.4 & 4 & 1150 & +2.6 & & \\
\hline GL 1-3 & 77 & -19.4 & & & 1141 & +2.3 & 3.2 & 8 & 1170 & +2.4 & & \\
\hline GL $1-3$ & & & & & & & 3.8 & 6 & 1270 & +2.7 & & \\
\hline Average & & & & & $1164 \pm 32$ & $+3.05 \pm 1.06$ & & & $1197 \pm 64$ & $+2.55 \pm 0.15$ & -0.5 & 2.8 \\
\hline GL 1-3 CM & 92 & -19.4 & & & 1453 & +1.1 & 1.7 & 7 & 1490 & +2.4 & & \\
\hline GL 1-3 CM & 88 & -19.4 & & & 1383 & +1.0 & & & & & & \\
\hline Average & & & & & $1418 \pm 49$ & $+1.05 \pm 0.07$ & & & & & +1.4 & 4.8 \\
\hline \multicolumn{13}{|l|}{$\begin{array}{l}\text { Not well cryst. } \\
\text { graphites }\end{array}$} \\
\hline GL 4-3 & 64 & -14.7 & 0.72 & 7.6 & 42 & +3.3 & 3.5 & 30 & 44 & +4.0 & & \\
\hline GL 4-3 & 65 & -14.6 & 0.66 & 10.6 & 27 & +8.9 & 2.0 & 33 & 67 & +1.0 & & \\
\hline GL 4-3 & & & & & & & 1.6 & 17 & 67 & +2.0 & & \\
\hline $\begin{array}{l}\text { GL } 4 \text {-3-degassed } \\
\text { at } 700^{\circ} \mathrm{C}\end{array}$ & 61 & -14.8 & 0.16 & 6.2 & 21 & +3.9 & & & & & & \\
\hline $\begin{array}{l}\text { GL } 4 \text {-3-degassed } \\
\text { at } 900^{\circ} \mathrm{C}\end{array}$ & 64 & -14.7 & 0.34 & 10.9 & 24 & +4.9 & & & & & & \\
\hline $\begin{array}{l}\text { GL 4-3-degassed } \\
\text { at } 1100^{\circ} \mathrm{C}\end{array}$ & 66 & -14.6 & 0.21 & 7.4 & 27 & +3.5 & & & & & & \\
\hline $\begin{array}{l}\text { GL 4-3-degassed } \\
\text { at } 1100^{\circ} \mathrm{C}\end{array}$ & 63 & -14.5 & 0.29 & 4.4 & 25 & +7.7 & & & & & & \\
\hline Average & $\begin{array}{l}64 \\
\pm 2\end{array}$ & $\begin{array}{l}-14.6 \\
\pm 0.11\end{array}$ & & & $28 \pm 7.4$ & $+5.4 \pm 2.37$ & & & $59 \pm 13$ & $+2.3 \pm 1.6$ & -3.1 & 52.6 \\
\hline \multicolumn{13}{|l|}{ Graphites } \\
\hline FGR 218-1 & 86 & -23.8 & 0.40 & 88 & 0.5 & +24.0 & & & & & & \\
\hline FGR 240-2 & 93 & -23.5 & 0.34 & 62 & 1.9 & +5.3 & & & & & & \\
\hline FGR 132-2 & n.d. & n.d. & 0.26 & 62 & 1.6 & +8.6 & & & & & & \\
\hline FGR 227-2 & 93 & -25.9 & 0.31 & 50 & 3.3 & +23.5 & & & & & & \\
\hline FRG 227-1 & 93 & -25.2 & 0.24 & 68 & 1.3 & +16.0 & & & & & & \\
\hline FGR 2984 & 97 & -12.6 & 0.24 & 68 & 1.5 & +17.0 & & & & & & \\
\hline FGR 169-8 & 95 & -15.3 & 0.36 & 92 & 0.3 & +10.2 & & & & & & \\
\hline FGR 241-I & 97 & -7.0 & 0.31 & 63 & 1.7 & +11.5 & & & & & & \\
\hline FRG 279-2 & & & & & & & 2.7 & 98 & 0.4 & +4.7 & & \\
\hline
\end{tabular}


Table 3 (continued)

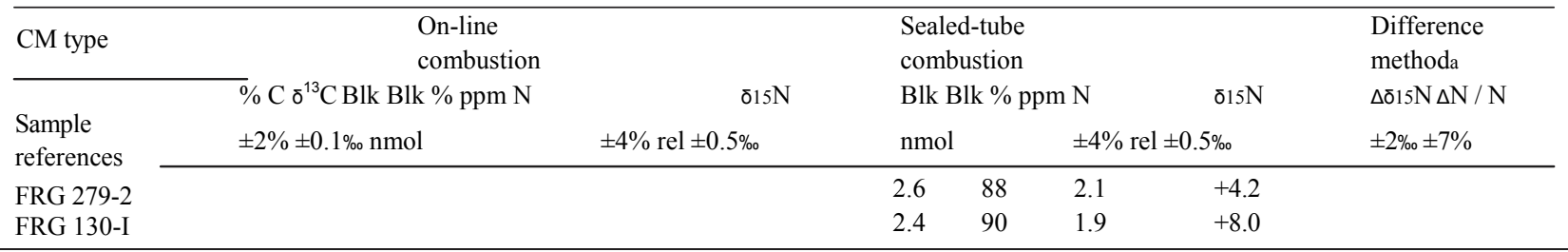

Blanks are calculated using the ${ }^{40} \mathrm{Ar}, \mathrm{N}$ contents are corrected from them when available, or otherwise from the blank of analysis (1.1 $\left.\pm 0.5 \mathrm{nmol}\right)$. $\delta^{15} \mathrm{~N}$ values are not corrected from the blank.

a Differences between on-line and sealed-tube combustion results: ${ }^{\Delta 15 N=} \delta^{15 N}$ sealed-tube ${ }^{-} \delta^{15 N}$ on-line and $\Delta \mathrm{N} / \mathrm{C}=\left(\mathrm{N} / \mathrm{C}\right.$ sealed-tube ${ }^{-} \mathrm{N} / \mathrm{C}$ on-line $) / \mathrm{N} /$ Csealed-tube.

${ }^{\mathrm{b}}$ Measurement performed by sealed-tube combustion and dual inlet mass spectrometry reported in Ader et al. (1998a,b).

contribution to the atmospheric ${ }^{40} \mathrm{Ar}$ from ${ }_{40}$ Arproduced by radioactive decay of ${ }^{40} \mathrm{~K}$ in the rock matrix or carbonaceous matter cannot be ruled out.

The combusted sealed-tube is introduced in the cracker section of the extraction-line (Fig. 1) and degassed for 48 $\mathrm{h}$ until the vacuum reaches the value of $2 \times 10^{-8}$ torr. Gases contained in the tube are ready to be released and transferred into the purification section.

Samples for the determination of $\delta^{13} \mathrm{C}$ and carbon content were prepared by sealed-tube combustion in a similar but simpler way than for $\delta^{15} \mathrm{~N}$ analyses. After $\mathrm{CuO}$ and quartz tube purification at $950{ }^{\circ} \mathrm{C}$ in air, between 1 and $5 \mathrm{mg}$ of powder sample (bulk rock or extracted carbonaceous matter) is introduced in the tube on top of the $\mathrm{CuO}$. The tube is then evacuated for one night under vacuum at ambient temperature and sealed when the vacuum is better than $10^{-5}$ torr. Combustion of the sealed-tube is done at $950{ }^{\circ} \mathrm{C}$ for $6 \mathrm{~h}$. Purification (using a liquid nitrogen trap) and quantification (using a Toepler manometer) of the produced $\mathrm{CO}_{2}$ were performed on a dedicated vacuum line. $\delta^{13} \mathrm{C}$ measurements were performed on a dual-inlet Delta E Finnigan Mat mass spectrometer. Reproducibility is better than $\pm 5 \%$ of the measured value for carbon content and $\pm 0.1 \%$ for the $\delta^{13} \mathrm{C}$.

\subsection{On-line combustion}

The on-line combustion section is made of three distinct subsections (Fig. 1 and Boyd et al., 1995): (i) the sample reactor, (ii) a $\mathrm{CuO}$ furnace providing $\mathrm{O}_{2}$ to combust the sample and (iii) a $\mathrm{Cu}-\mathrm{CaO}$ furnace allowing both the sequestration of $\mathrm{CO}_{2}$ as $\mathrm{CaCO}_{3}$ and the reduction of $\mathrm{NO}_{x}$ into $\mathrm{N}_{2}$. The sample embedded in platinum foil is degassed (b10 $0^{-7}$ torr) in a side arm of the vacuum line at ambient temperature overnight. The sample is then introduced in the sample reactor at a temperature of $400{ }^{\circ} \mathrm{C}$ or higher in the case of graphite analysis. When the pressure reaches the minimum value of $2 \times 10^{-8}$ torr, the $\mathrm{CaO}-\mathrm{Cu}$ furnace (when unused set at $850{ }^{\circ} \mathrm{C}$ ) is cooled to $100{ }^{\circ} \mathrm{C}$ to prevent oxidation of the $\mathrm{Cu}$ during the combustion period. The combustion system is isolated from the pumps; the reactor and $\mathrm{CuO}$ furnaces are set to the temperature of 1100 and $930{ }^{\circ} \mathrm{C}$ respectively for the combustion. A liquid nitrogen trap is placed below the reactor, trapping the evolved $\mathrm{CO}_{2}$. As a consequence the oxygen pressure is not diluted by stagnant $\mathrm{CO}_{2}$ and the rate of combustion is enhanced (Javoy et al., 1984), 2 mg of graphite being combusted in less than $15 \mathrm{~min}$. After the combustion, the temperature of the $\mathrm{CuO}$ furnace is set down to $450{ }^{\circ} \mathrm{C}$ to re-fix oxygen. The $\mathrm{CaO}-\mathrm{Cu}$ furnace temperature is then raised to $600{ }^{\circ} \mathrm{C}$ and the liquid nitrogen trap is removed. The $\mathrm{CO}_{2}$ reacts with the $\mathrm{CaO}$ and the $\mathrm{NO}_{x}$ react with $\mathrm{Cu}$ to produce $\mathrm{N}_{2}$. The $\mathrm{CaO}-\mathrm{Cu}$ furnace is then cooled to $100{ }^{\circ} \mathrm{C}$ in order to reduce the residual pressure of $\mathrm{CO}_{2}$. The residual $\mathrm{N}_{2}$ is ready to be transferred into the purification section. Nitrogen blanks are of $0.28 \pm 0.14 \mathrm{nmol} \mathrm{N}$. The $\mathrm{CO}_{2}$ produced during the combustion and fixed as $\mathrm{CaCO}_{3}$ is released by setting the $\mathrm{CaO}$ furnace to $850{ }^{\circ} \mathrm{C}$. It is quantified using a calibrated piezo-resistive gauge (precision \pm $5 \%$ ) and analysed for the $\delta^{13} \mathrm{C}$ on a conventional dualinlet Delta E Finnigan Mat mass spectrometer.

3.4. Nitrogen purification, quantification and isotopic analysis

The gases produced either by sealed-tube or on-line combustion are transferred into the purification section (Fig. 1) where (i) traces of $\mathrm{CO}$ if any are oxidized to $\mathrm{CO}_{2}$ by $\mathrm{CuO}$ heated at $450{ }^{\circ} \mathrm{C}$ and (ii) all condensable gases are trapped cryogenically. The purified $\mathrm{N}_{2}$ is quantified using a capacitance manometer before being introduced in the triple collector static vacuum mass spectrometer connected to the line. The amount of nitrogen is measured with a precision better than $\pm 8 \%(2 \sigma)$ and the $\delta_{15} \mathrm{~N}$ values is measured with an accuracy of $\pm 0.5 \%(2 \sigma)$ (Busigny et al., 2005). Because isobaric interferences of 
Table 4

Atomic N / C ratio and ${ }_{615}$ obtained by sealed-tube combustion for bulk samples and their carbonaceous matter (CM)

\begin{tabular}{|c|c|c|c|c|c|c|c|}
\hline Sample references & $\% \mathrm{C} \pm 2 \%$ & ${ }^{6}{ }^{13} \mathrm{C} \pm 0.1 \% \circ$ & Blank (nmol) & Blank (\%) & $\mathrm{N} / \mathrm{C} \mathrm{ppma}$ & ${ }_{6} 155_{N+0.5 \%}$ & ${ }_{6} 15_{N}$ blank corrected \\
\hline \multicolumn{8}{|l|}{$\mathrm{N} / \mathrm{C}_{\mathrm{Bu} 1 \mathrm{k}}>\mathrm{N} / \mathrm{C}_{\mathrm{CM}}$} \\
\hline DS6 & 55 & -24.4 & 3.9 & 1 & $2387 \pm 108$ & +4.3 & $+4.3 \pm 0.5$ \\
\hline DS6 CM & 96 & -24.1 & 2.9 & 8 & $1159 \pm 48$ & +1.1 & $+0.9 \pm 0.8$ \\
\hline DS7 & 68 & & 3.0 & 2 & $1617 \pm 62$ & +3.4 & $+3.4 \pm 0.5$ \\
\hline DS7 CM & 96 & -24.6 & 1.9 & 5 & $991 \pm 36$ & +2.1 & $+2.0 \pm 0.6$ \\
\hline GL 4- & 65 & -14.7 & 1.6 & 17 & $88 \pm 7$ & +2.0 & $+1.6 \pm 1.5$ \\
\hline GL 4-3 & & & 2.4 & 39 & $88 \pm 19$ & +1.0 & $-0.9 \pm 5.5$ \\
\hline GL 4-3 & & & 4.2 & 35 & $58 \pm 11$ & +4.0 & $+4.0 \pm 4.3$ \\
\hline GL 4-3CM & 94 & -14.7 & 3.6 & 44 & $45 \pm 12$ & +2.7 & $+1.7 \pm 7.2$ \\
\hline \multicolumn{8}{|l|}{$\mathrm{N} / \mathrm{C}_{\mathrm{B} u 1 \mathrm{k}}-\mathrm{N} / \mathrm{C}_{\mathrm{C} \mathrm{M}}$} \\
\hline DS5 & 64 & & 3.1 & 3 & $1487 \pm 61$ & +3.1 & $+3.1 \pm 0.5$ \\
\hline DS5CM & 92 & -24.5 & 1.7 & 3 & $1592 \pm 55$ & +2.5 & $+2.5 \pm 0.6$ \\
\hline Average & & & & & $1540 \pm 75$ & $+2.8 \pm 0.4$ & $+2.8 \pm 0.5$ \\
\hline GL 1-3 & 76 & -19.4 & 3.4 & 4 & $1293 \pm 49$ & +2.6 & $+2.5 \pm 0.6$ \\
\hline GL 1-3 & & & 3.2 & 8 & $1316 \pm 63$ & +2.4 & $+2.3 \pm 0.8$ \\
\hline GL 1-3 & & & 3.8 & 6 & $1433 \pm 60$ & +2.7 & $+2.6 \pm 0.7$ \\
\hline GL 1-3 CM & 92 & -19.4 & 1.7 & 7 & $1389 \pm 58$ & +2.4 & $+2.3 \pm 0.8$ \\
\hline Average & & & & & $1358 \pm 65$ & $+2.5 \pm 0.2$ & $+2.4 \pm 0.6$ \\
\hline GL 2-3 & 81 & -18.0 & 3.1 & 26 & $109 \pm 14$ & +6.7 & $+7.7 \pm 2.6$ \\
\hline GL 2-3 CM & 95 & n.d. & 3.9 & 26 & $112 \pm 14$ & +7.7 & $+9.0 \pm 2.6$ \\
\hline Average & & & & & $110 \pm 14$ & $+7.2 \pm 0.7$ & $+8.3 \pm 2.6$ \\
\hline GL 3-3 & 87 & -21.5 & 3.1 & 41 & $39 \pm 9$ & +4.7 & $+5.2 \pm 5.9$ \\
\hline GL 3-3 CM & 95 & -21.4 & 4.3 & 42 & $38 \pm 9$ & +4.3 & $+4.5 \pm 6.4$ \\
\hline GL 3-3 CM & & & 3.4 & 32 & $62 \pm 10$ & +4.7 & $+5.0 \pm 3.5$ \\
\hline Average & & & & & $46 \pm 14$ & $+4.6 \pm 0.3$ & $+4.9 \pm 3.5$ \\
\hline \multicolumn{8}{|l|}{$\mathrm{N} / \mathrm{C}_{\mathrm{Bu} 1 \mathrm{k}}<\mathrm{N} / \mathrm{C}_{\mathrm{CM}}$} \\
\hline BM6 & 86 & -22.2 & 2.3 & 15 & $105 \pm 7$ & +4.7 & $+4.8 \pm 1.3$ \\
\hline BM6 & & & 5.1 & 34 & $105 \pm 18$ & +3.6 & $+3.4 \pm 3.9$ \\
\hline BM6 CM & 99 & -22.3 & 3.4 & 20 & $127 \pm 12$ & +2.4 & $+2.0 \pm 1.9$ \\
\hline $\mathrm{CM} 1100^{\circ} \mathrm{C}$ pyrolysis & & & 4.6 & 18 & $111 \pm 8$ & +2.8 & $+2.5 \pm 1.6$ \\
\hline BM 21 & 50 & -21.5 & 1.9 & 9 & $113 \pm 6$ & +9.6 & $+10.1 \pm 0.8$ \\
\hline $\mathrm{BM} 21 \mathrm{CM}$ & 94 & -21.6 & 5.4 & 14 & $251 \pm 16$ & -1.3 & $-2.2 \pm 1.3$ \\
\hline $\mathrm{CM} 1100^{\circ} \mathrm{C}$ pyrolysis & & & 1.5 & 7 & $133 \pm 5$ & +3.4 & $+3.4 \pm 0.7$ \\
\hline BM44 & 73 & -21.0 & 2.5 & 32 & $58 \pm 10$ & +8.3 & $+10.3 \pm 3.7$ \\
\hline BM44 & & & 3.1 & 28 & $46 \pm 6$ & +10.0 & $+12.3 \pm 3.0$ \\
\hline BM44 CM & 100 & -21.2 & 6.0 & 26 & $162 \pm 20$ & -2.2 & $-4.4 \pm 2.8$ \\
\hline $\mathrm{CM} 1100^{\circ} \mathrm{C}$ pyrolysis & & & 2.5 & 34 & $50 \pm 8$ & +2.3 & $+1.4 \pm 3.9$ \\
\hline
\end{tabular}

${ }_{a} \mathrm{~N} / \mathrm{C}$ in ppm: atomic N/ C ratio $\times 10_{6}$.

separates were analysed by on-line combustion, the other two by sealed-tube combustion. Results are reported in Table 3 along with the C-content and $6{ }^{13} \mathrm{Cobtained}$

CO lead to a significant increase of a s $_{\mathrm{N}}$ values (Javoy et al., 1984; Beaumont et al., 1994), the purity of the analysed $\mathrm{N}_{2}$ with respect to $\mathrm{CO}$ is checked for each sample by monitoring both the mass-to-charge ratio of 12 and half-life of $\mathrm{N}_{2}$ species.

\section{Results and discussion}

4.1. Comparison of sealed-tube and on-line combustion methods to determine $\mathrm{N}$-content and $8^{15} \mathrm{~N}$ in carbonaceous-rich metasediments simultaneously by on-line combustion.

For on-line combustion the N-content reproducibility is better than $\pm 4 \%$ ( $1 Q$ ) of the measured value (Table 3 ). The ${ }_{6} 15_{\mathrm{N}}$ reproducibility (1Q) calculated for samples analysed several times (GP, PIES-6770, GL 3-1) are comprised between $\pm 1 \%$ o and $\pm 2 \%$ o. This is rather poor compared to the expected $\pm 0.5 \%$ o (1Q) obtained for the analyses of micro-diamonds using exactly the same equipment and analytical protocol (see Table 1 in Cartigny et al., 2001).

Nine bulk samples and the carbonaceous matter (extracted by $\mathrm{HF} / \mathrm{HCl}$ ) of one of them (GL 3-1) were analysed by both methods. Nine of the eleven graphite 
Table 5

Carbonaceous matter atomic $\mathrm{N} / \mathrm{C}$ (corrected from the blank) ratio and $6{ }_{15} \mathrm{~N}$ for samples of coal origin

\begin{tabular}{|c|c|c|c|c|c|c|c|}
\hline Sample references & $\mathrm{XRD} \mathrm{d}_{002} \AA$ & $\% \mathrm{C} \pm 2 \%$ & $61{ }_{3} \mathrm{C} \pm 0.1 \% \circ$ & $\mathrm{n}_{\mathrm{a}}$ & Blank (\%) & Organic N / C ppm ${ }^{b}$ & $615 \mathrm{~N}(\% \circ)$ \\
\hline DS2 CM & 3.58 & 89 & -23.6 & 1 & 3 & $3464 \pm 220$ & $-0.7 \pm 0.6$ \\
\hline DS1 CM & 3.52 & 92 & -24.2 & 1 & 4 & $4051 \pm 240$ & $+1.8 \pm 0.6$ \\
\hline BU1 CM & 3.52 & 90 & -23.1 & 1 & 9 & $2744 \pm 123$ & $+1.9 \pm 0.8$ \\
\hline DS5 CM & $3.37-3.38$ & 92 & -24.5 & 1 & & $1540 \pm 75$ & $+2.7 \pm 0.5$ \\
\hline DS6 CM & $3.37-3.38$ & 96 & -24.1 & 1 & 8 & $1159 \pm 80$ & $+0.9 \pm 0.8$ \\
\hline DS7 CM & $3.37-3.38$ & 96 & -24.6 & 1 & 5 & $991 \pm 60$ & $+2.0 \pm 0.6$ \\
\hline DS4 CM & $3.37-3.38$ & 93 & -24.3 & 1 & 4 & $1626 \pm 110$ & $+1.9 \pm 0.6$ \\
\hline GL 1-3 CM & & 92 & -19.4 & 4 & & $1360 \pm 64$ & $+2.4 \pm 0.7$ \\
\hline GL 2-3 CM & & 95 & -18.0 & 2 & & $<110 \pm 14$ & \\
\hline GL 3-3 CM & & 95 & -21.5 & 3 & & $: 546 \pm 15$ & \\
\hline GL 4-3 CM & & 94 & -14.7 & 4 & & $: 570 \pm 22$ & \\
\hline BM6CM & 3.364 & 99 & -22.3 & 3 & & $<112 \pm 11$ & \\
\hline BM21 CM & 3.365 & 94 & -21.6 & 1 & & $<113 \pm 6$ & \\
\hline BM44 CM & 3.360 & 100 & -21.3 & 1 & & $: 550 \pm 8$ & \\
\hline
\end{tabular}

${ }^{a} \mathrm{n}$ : number of analyses. For samples having bulk N / C equal to CM N / C (see Table 4), bulk samples analyses are considered as replicate of the CM ones.

${ }^{\mathrm{b}}$ Organic $\mathrm{N} / \mathrm{C}$ in ppm=atomic organic $\mathrm{N}$-to-organic $\mathrm{C}$ ratio $\times 10_{6}$.

For sealed-tube combustion, N-rich samples (>_1000 ppm N; meta-anthracite, semi graphite and solid bitumen) $\mathrm{N}$-content and ${ }_{6} 15_{\mathrm{N}}$ reproducibility is better than $4 \%(1 \mathrm{Q})$ and $\pm 0.7 \%$ o (1Q) respectively, i.e. better than for on-line combustion analyses although not as good as can be expected from Busigny et al. (2005). The results obtained for the sample PIES-6770 are within error of a previous determination using sealed-tube combustion and dual inlet mass spectrometry $(\mathrm{N}=0.45 \pm$ $0.03 \%, 8^{15} \mathrm{~N}=3.45 \pm 0.15 \% 0$; Ader et al., 1998a). For a low N-content sample (not well crystallized graphite GL $3-4$; around $60 \mathrm{ppm} \mathrm{N}$ ) the results are not reproducible $\left(6^{15} \mathrm{~N}=2.3 \pm 1.6 \%_{0}\right)$, reflecting a higher proportion of blank (between 15\% and 35\%) in the analysed N2. For very low $\mathrm{N}$-content samples (graphites containing less than $3.5 \mathrm{ppm} \mathrm{N}$ ), the high proportion (more than $88 \%$ ) of blank in the analysed $\mathrm{N}_{2}$ did not allow any reliable $615 \mathrm{~N}$ measurement.

The results obtained by both methods are reproducible enough to see that they are frequently different from each other. For example, the PIES-6770 sample $615 \mathrm{~N}$ measured by on-line combustion is of $-2.6 \pm 1.3 \%$ o when this value measured by sealed-tube combustion is of $+3.5 \pm 0.7 \%$ o. The corresponding atomic $\mathrm{N} / \mathrm{C}$ ratio is of $4007 \pm 200 \mathrm{ppm}$ by on-line combustion and of $4655 \pm$ 220 ppm by sealed-tube combustion. In Fig. 2, the results acquired on the same starting material are compared by plotting ${ }^{015} \mathrm{~N}=\mathrm{a}^{15} \mathrm{~N}$ sealed-tube- $\mathrm{a}^{15} \mathrm{~N}$ on-line versus $\mathrm{AN}$

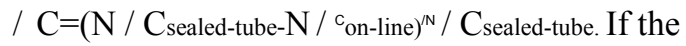
methods gave the same results, all the points should fall around zero on both scales. Instead, they define a trend of increasing ${ }_{\mathrm{A}} 15 \mathrm{~N}$ with increasing $\mathrm{AN} / \mathrm{C}$ indicating that

on-line combustion yields less nitrogen with lower $615 \mathrm{~N}$ values (down to $-6.2 \%$ ) than sealed-tube combustion.

The difference in $\mathrm{N}$ content between the two methods cannot be due to a source of extra nitrogen brought by the sealed-tube method - namely atmospheric and/or modern organic contamination - since the blanks are very low and the potential modern organic contaminations have been removed (see Section 3.2 and Busigny et al.,

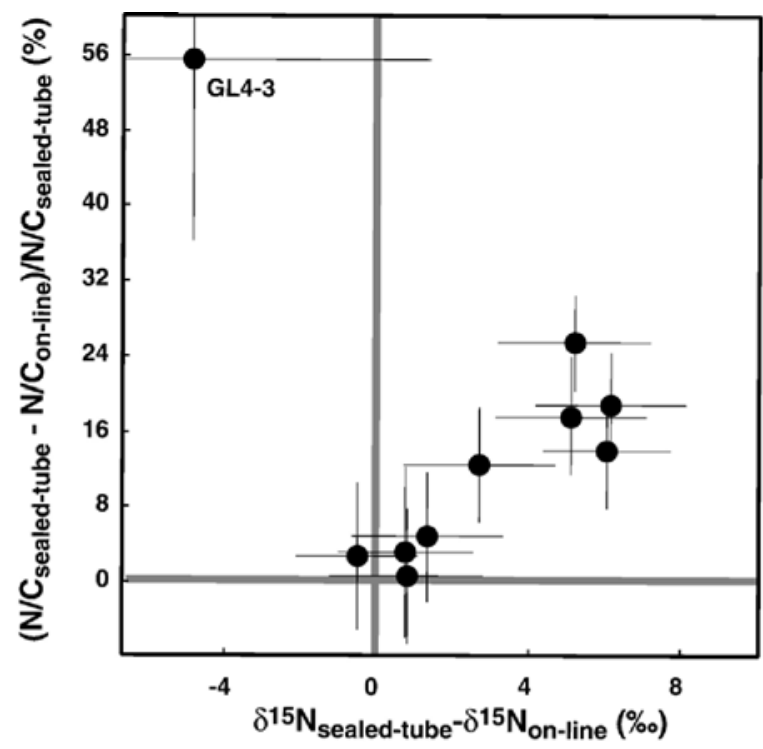

Fig. 2. Results acquired by on-line and sealed-tube combustion methods are compared by plotting $A{ }^{15} \mathrm{~N}=6{ }^{15} \mathrm{~N}_{\text {sealed-tube }-} 6{ }^{15} \mathrm{~N}_{\text {on-line }}$ versus $\mathrm{AN} / \mathrm{C}=\left(\mathrm{N} / \mathrm{C}_{\text {sealed-tube- }} \mathrm{N} / \mathrm{C}_{\text {on-line }}\right) / \mathrm{N} / \mathrm{C}_{\text {sealed-tube. }}$ All the points should fall close to zero on both scales if both methods were giving the same results. 
2005). The difference in $\mathrm{N}$ content between the two methods can only be due to poor nitrogen recovery by on-line combustion, showing that the on-line combustion method described in this paper is not suitable for the $\mathrm{N}$-content and $\delta^{15} \mathrm{~N}$ analysis of carbonaceous-rich metamorphic rocks. In contrast, the sealed-tube combustion technique is a reproducible and accurate method for the determination of nitrogen content and $\delta^{15} \mathrm{~N}$ in organic rich metamorphic rocks - provided that the nitrogen concentration is high enough with respect to the nitrogen blank $(3 \pm 1.5 \mathrm{nmol} \mathrm{N})$ - a conclusion in agreement with that of Bräuer and Hahne (2005) who recently demonstrated that for carbonaceous-rich samples the sealedtube combustion method yields $\mathrm{N}$ content and $\delta_{15} \mathrm{~N}$ results identical to digestion techniques.

Among the possible reasons for the inadequacy of the on-line combustion for the $\mathrm{N}$ content and $\delta^{15} \mathrm{~N}$ analysis of carbonaceous-rich rocks, a general dysfunction of the on-line combustion section can be ruled out as a microdiamonds powder analysed during the same period gave fully consistent results $\left(\delta^{15} \mathrm{~N}\right.$ and $\mathrm{N}$ content reproducibility are $\pm 0.5 \%(1 \sigma)$ and $\pm 2.5 \%$ ( $1 \sigma)$ respectively, $\mathrm{n}=4)$. Incomplete combustion of organic nitrogen can also be ruled out as combustions of pure graphite samples yielded $100 \%$ of carbon recovery and further combustion of the samples produced only blank amounts of $\mathrm{CO}_{2}$. Incomplete release of fixed-ammonium - as suggested from similar poor $\mathrm{N}$ recovery with lower $\delta^{15} \mathrm{~N}$ by elemental analysis coupled to mass spectrometry (Bräuer and Hahne, 2005) - can also be ruled out since it was shown that vacuum pyrolysis at $1100{ }^{\circ} \mathrm{C}$ using the same apparatus releases most of the fixed nitrogen from metamorphic rocks (Boyd et al., 1993; Boyd, 1997) and the presence of $\mathrm{O}_{2}$ during the combustion step at $1100{ }^{\circ} \mathrm{C}$ is expected to enhance the release of fixed ammonium. The fact that the nitrogen content and $\delta^{15} \mathrm{~N}$ differences are relatively reproducible for each sample, but very different from one sample to another, points out to a matrix effect. If all the nitrogen is released from the sample during on-line combustion, its incomplete recovery could be explained by secondary gas phase reactions with impurities (such as sulphur and metals, absent from diamonds but frequently present in carbonaceous-rich metamorphic rocks) occurring at some stage of the combustion process. The speciation of the nitrogen $\left(\mathrm{N}_{2}, \mathrm{NO}_{\mathrm{x}}\right)$ involved in these reactions and the nature of the condensed phase are unknown but the following observations seem to validate this hypothesis: after several online combustions yellow deposits have been observed on the unheated glass walls adjacent to the $\mathrm{Cu} / \mathrm{CaO}$ furnace, and blank increase after a combustion (up to 1.4 after instead of $0.3 \mathrm{nmol}$ before, while the ${ }^{40} \mathrm{Ar}$ remainedconstant) suggested that some nitrogen was stored in the on-line combustion section during the sample combustion and partly remobilised during the following blank. The fact that these reactions do not occur during sealed-tube combustion suggests that they are due to temperature and/or oxygen fugacity contrasts: during combustion, the whole sealed-tube (sample and reactants) is heated at homogeneous temperature, as opposed to the on-line combustion with different subsections characterised by contrasting temperature and oxygen fugacity.

The present results indicate the need to use the sealedtube technique as a reference method as it circumvents all kinds of matrix-related problems.

4.2. Consequences of carbonaceous matter extraction: nitrogen in $\mathrm{CM}$ versus nitrogen in bulk rock

The impact of the $\mathrm{HCl} / \mathrm{HF}$-attack on the $\delta^{15} \mathrm{~N}$ of the carbonaceous matter is investigated here with a special interest in potential nitrogen contamination of samples containing less than $100 \mathrm{ppm} \mathrm{N}$, an often-neglected issue. Bulk powder and isolated CM of 10 samples were analysed by sealed-tube combustion. For most of these samples it is assumed that carbon is mostly only present in the carbonaceous matter and is therefore totally preserved during the CM extraction. DS and BM samples did not show carbonate by XRD and all the samples (even the GL samples for which $\delta^{13} \mathrm{C} \mathrm{N}-20 \%$ suggest isotopic equilibration with carbonate) show similar $\delta_{13} \mathrm{C}$ for the bulk sample and the carbonaceous matter, indicating the absence of carbonate.

For the purpose of the discussion, samples are divided in three groups (Table 4).

- The first group is characterised by bulk samples (3 samples) presenting a higher $\mathrm{N} / \mathrm{C}$ ratio than their $\mathrm{CM}$. These samples illustrate the presence of fixedammonium. Significant differences between $\delta^{15} \mathrm{~N}$ in the bulk and in the CM (up to $3.4 \%$ for DS6) demonstrate that carbonaceous matter extraction is needed.

- The second group of samples (4 samples) shows similar atomic $\mathrm{N} / \mathrm{C}$ ratios in bulk samples and their $\mathrm{CM}$. These samples illustrate the absence of fixedammonium. In this case the similarity between $\delta_{15} \mathrm{~N}$ in bulk samples and their $\mathrm{CM}$ demonstrate that the procedure of CM extraction did not affect its $\delta_{15} \mathrm{~N}$.

- In the third group of samples (3 samples) nitrogen associated with the $\mathrm{HF} / \mathrm{HCl}$ isolated carbonaceous matter displays a higher atomic $\mathrm{N} / \mathrm{C}$ ratio and a lower $\delta^{15} \mathrm{~N}$ (down to $-10 \%$ ) than in the bulk sample. This illustrates a nitrogen contamination, which may have been introduced through fluorite precipitation during 


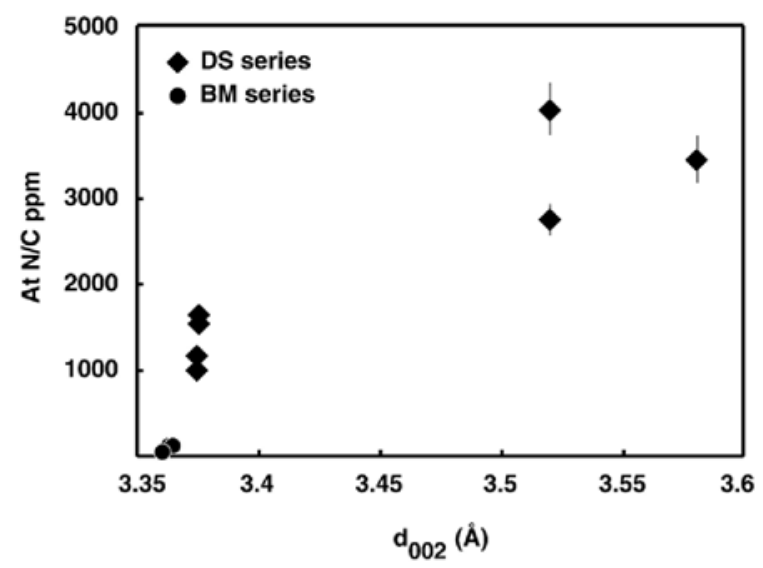

Fig. 3. Carbonaceous matter atomic N / C ratio of the DS and BM graphitisation series versus the graphitic interlayer spacing 4002 obtained by XRD - used here to evaluate the structural organisation of the carbonaceous matter.

the $\mathrm{HCl} / \mathrm{HF}$ treatment (see also Van Zuilen et al., 2005). As tested with the BM6 sample, this contamination can be partly removed by a pyrolysis step at $1100{ }^{\circ} \mathrm{C}$.

If up to 100 ppm $\mathrm{N}$ contamination can occur during $\mathrm{CM}$ extraction of samples initially containing more than $50 \%$ of carbon, one can question the quality of $\mathrm{CM}$ extraction for most metasedimentary rocks usually containing less $2 \%$ carbonaceous matter of low $\mathrm{N} / \mathrm{C}$. Controlling the $\mathrm{CM}$ purity, and rejecting suspicious ones, as done by Van Zuilen et al. (2005), is then necessary. In our case, the absence of control on the presence and/or total removal of the contamination on data obtained for CM containing very low $\mathrm{N}$ content ( $<200$ ppm; BM and GL series) lead us to consider their $\mathrm{N}$ content as maximum estimates and ${ }_{61} 5_{\mathrm{N}}$ as irrelevant.

\subsection{Trends of organic nitrogen content and $8{ }_{15} \mathrm{~N}$ during metamorphism}

\subsubsection{Results}

In the present work (Tables 3 and 5) we found that atomic $\mathrm{N} / \mathrm{C}$ ratios $\left(\times 10^{6}\right)$ are comprised between: (1) 2500 and 4050 in meta-anthracites, (2) 990 and 1600 in semi-graphites, (3) 45 and 110 in not well crystallized graphites, (4) and finally that they are lower than 3 in graphites. Table 5 and Fig. 3 also show that nitrogen is efficiently removed from the carbonaceous matter during graphitization (decreasing interplanar spacing ${ }_{\text {sans }}$ in both DS and BM series. In the absence of a conventional maturation index, the $\mathrm{CM}$ atomic $\mathrm{N} / \mathrm{C}$ ratio could therefore be used as such. The ${ }_{615}$ results obtained onthe DS series for the metagenesis stage (i.e. meta-anthracite to semi-graphite stages) are presented in Fig. 4 versus their $\mathrm{CM}$ atomic $\mathrm{N} / \mathrm{C}$ ratios used as a maturation index. $\mathrm{CM}$ atomic $\mathrm{N} / \mathrm{C}$ ratios $\left(\times 10^{6}\right)$ are comprised between 990 and 4050. They are not correlated with organic $8^{15} \mathrm{~N}$ values, which range between $-0.7 \% \circ \pm 0.6 \% \circ$ and $+2.7 \pm 0.5 \%$ o $(\mathrm{n}=7)$. The average $1 \%$ o increase between the meta-anthracite samples and the semi-graphite samples cannot be considered as significant compared to the $8{ }^{15} \mathrm{~N}$ internal variability of both the metaanthracite and semi-graphite samples (respectively $3 \mathrm{~N}_{\mathrm{o}}$ and 2 No).

These results complete the available picture of the trends of organic nitrogen content and $6_{15} \mathrm{~N}$ during diagenesis and metamorphism. Previous studies did not find any clear type III kerogen $8^{15} \mathrm{~N}$ change neither during diagenesis, where organic nitrogen is largely preserved (Fig. 4; Boudou et al., 1984; Rigby and Batts, 1986; Whiticar, 1996), nor during the early stages of metagenesis - anthracite to meta-anthracite stages - (Fig. 4; Rigby and Batts, 1986; Ader et al., 1998a), in spite of a significant mineralization of organic nitrogen - organic atomic $\mathrm{N} / \mathrm{C}$ ratio decreasing down to $0.5 \%$ (see also Volkova and Bogdanova, 1989; Daniels and Altaner, 1990, 1993). The present work brings the first N / C and $6^{15} \mathrm{~N}$ data on $\mathrm{cm}$ nitrogen mineralization process during the next stage of metagenesis - meta-anthracite to semigraphite stages - and suggests that ${ }^{15} \mathrm{~N}$ would remain about the same during metamorphism, which implies that, organic nitrogen (whatever the initial kerogen path) would be mineralized without any isotopic fractionation.

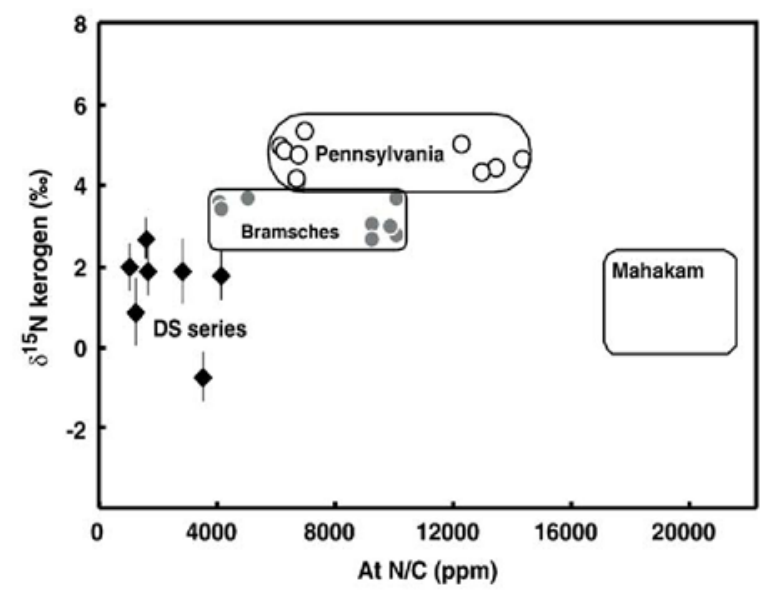

Fig. 4. Carbonaceous matter ${ }_{6} 15_{\mathrm{N}}$ for the DS semi-graphitisation series are reported as a function of atomic N / C ratio. Previous data are also reported for comparison: Pennsylvania and Bramsche Massif metaanthracitisation series (Ader et al., 1998a); Mahakam burial diagenesis series (Boudou et al., 1984). 
During the last metagenesis stages - semi-graphite to graphite - mean nitrogen content further decreases down to 10 to $60 \mathrm{ppm} \mathrm{N}$ in relatively well crystallized graphite (see also Van Zuilen et al., 2005), and down to less than $3 \mathrm{ppm}$ in well crystallized graphite, but its $\delta^{15} \mathrm{~N}$ evolution remains to be constrained.

4.3.2. Inferences on the process of organic nitrogen mineralization during metagenesis

Our study suggests that, in spite of a large nitrogen mineralization, metamorphism would not produce any significant change in organic $\delta^{15} \mathrm{~N}$. The observed organic nitrogen $\delta^{15} \mathrm{~N}$ steadiness provides constraints on both the nitrogen mineralization process and the general natural process of low to high-pressure structural transformations of the carbonaceous matter, which remains to be explored.

After sedimentary deposition and early diagenesis, the organic nitrogen-containing structures appear to be mostly pyrrolic and pyridinic (Burchill and Welch, 1989; Wojtowicz et al., 1995; Knicker et al., 1996; Kelemen et al., 1999, 2002; Bennett et al., 2004). The observed $\delta_{15} \mathrm{~N}$ constancy until the onset of oil/gas formation along the type III kerogen maturation path (Boudou et al., 1984; Rigby and Batts, 1986; Whiticar,1996) can be explained by internal structural rearrangements with only little organic nitrogen loss (Boudou et al., 1984; Boudou and Espitalié, 1995). At higher maturation grade, whatever the initial kerogen path, nitrogen appears to substitute to carbon in condensed polyaromatic systems. In this position, it could not be removed by pure thermal reactions, as shown with model compounds (Pan et al., 1966; Stanczyk and Boudou, 1994; Kelemen et al., 1999; Zolotov and Shock, 2001; Xiao et al., 2005), while it could be more easily mineralized by pressure reaction in water media, under sub- or supercritical conditions, with formation of ammonia and organic denitrogenated by products (Katritzky et al., 1995; Nakano et al., 2001; Akimoto et al., 2002, 2003). Previous gold cell experimental simulation of the co-evolution of carbonaceous matter and associated silicates during early metamorphism stages using model carbazole-kaolinite or anthracite-kaolinite mixtures showed that metamorphic pressure reaction, in presence of water resulting from the transformation of kaolinite into illite, produces a strong nitrogen mineralization without any mean carbonaceous matter $\delta^{15} \mathrm{~N}$ change (Ader et al., 1998a,b). For the more advanced metamorphic grades, experimental hydrothermal process, when applied to coal or amorphous carbon, can leave behind graphitic carbon (u.a. Tagiri and Oba, 1986; Jakobsson and Oskarsson, 1994; Kraft and Nickel, 2000; Libera and Gogotsi, 2001;

Calderon-Moreno and Yoshimura, 2002), and it is worthy to note that graphite particles have been reported in natural circulating hydrothermal fluids (Jedwab and Boulegue, 1984). The role of water as reactant in kerogen/CM denitrogenation has also been underlined in hydrocarbon and fluid formation by kerogen cracking (Everlien, 1997; Lewan, 1997; Price and Dewitt, 2001; Schimmelmann et al., 2001; Mastalerz and Schimmelmann, 2002; Schwab et al., 2005).

It is reasonable to assume that, whatever the initial type of kerogen, water would not penetrate quickly, through a microporous network, into the matrix of the resulting natural carbonaceous matter undergoing metamorphism, but would only slowly penetrate by a thermal activated solid phase diffusion forming an external front around the carbonaceous solid particle, where nitrogen mineralization, by oxy and hydroxyl radical attack, would progress more quickly to completion than the diffusion itself. Observations of the texture of metamorphic carbonaceous matter support this fluid transfer scheme. Anthracites have some mesopores and a closed micropore network (Fryer, 1981; Mahajan,1984; Daulan et al., 1998; Radlinski et al., 2004), which result from early cross-linking processes. Micropores correspond to the global misorientation of small nanometric BSU (usually stacking of two or three aromatic layers of 2$3 \mathrm{~nm}$ in diameter, as in most chars and cokes). Locally, 5 to $10 \mathrm{~nm}$ BSU domains tend to form pore walls of larger mesopores. Such domains are revealed in the HRTEM 002 dark field images (Rouzaud and Oberlin, 1990). The porous texture of carbonaceous matter derived from other kerogen types can be inferred from experimental slow carbonization of graphitizable precursors, such as algal ones, which produces a coalescence of the carbon matrix, foregoing oil/gas formation and leaving behind very little micropores, but large basic structural units which easily form planar graphite by high pressure breaking - along the graphitization Oberlin's model.

Along an incremental denitrogenation model, complete nitrogen loss of the residual carbon would occur at the external interface, before progressing towards the interior part of the solid, instead of occuring in the whole bulk solid, as it would be the case in a purely thermal denitrogenation process. Therefore carbonaceous matter denitrogenation with ammonia genesis, by pressure reaction in presence of water, would just concern the external grain interface without affecting the residual bulk nitrogen (very thermostable) where $\delta^{15} \mathrm{~N}$ would remain constant - as any possible thermal-reactions of ammonia contained in formation waters with carbonaceous matter would just concern the fully denitrogenated external interface. The water necessary for this reaction 
does not necessarily need to be introduced from an external source but could simply be produced in situ, by an illitization process (Ahn et al., 1999). In the case of HP-LT metamorphic series, another type of oriented nitrogen attack supporting the carbonaceous matter $\delta_{15} \mathrm{~N}$ steadiness can be deduced from HRTEM study of the natural graphitisation (Oberlin and Terrière, 1975; Bonijoly et al., 1982; Beyssac et al., 2002). High-pressure metamorphism would produce graphitic lamellae by breaking the carbon microtextures from previous lowpressure kerogen metamorphism (e.g. anthracite). From the mechanistic graphitization scheme, one can hypothesize that the rupture of micropore walls and onion like structures would locally produce edge lamellae nitrogen species prone to mineralization by interfacial incremental pressure reaction in water media leaving behind unchanged internal quaternary nitrogen. HP/HT experimental simulations conducted in the absence of water, explain the natural graphitization by tectonic stress, which - in addition to frictional heating and pressure ordering (Bustin et al., 1995; Nover et al., 2005) - is also known to facilitate the hydrothermal fluid circulation. This was explicitly quoted by Suchy et al. (1997), who suggest that the high temperatures responsible for the formation of 'transitional matter' and 'optical graphite' may be explained by two possible mechanisms: flow of hot brines through micro-shear zones or frictional heating during micro-shearing. In fact, the flow of hydrothermal fluids through organic-rich strata has been proposed as a general cause of coal metamorphism (Hower and Gayer, 2002).

4.3.3. Implications for the use of metasedimentary carbonaceous matter $\delta^{15} \mathrm{~N}$ as a paleoenvironmental indicator

Assuming that the carbonaceous matter, whatever its initial kerogen source, behaves similarly through the metamorphism, an important implication of the $\delta_{15} \mathrm{~N}$ steadiness is that it could be used as an estimate of CM $\delta^{15} \mathrm{~N}$ prior to metamorphism. Because of internal variations of the $\delta^{15} \mathrm{~N}$ values of the DS series, the accuracy of the estimate is only of $\pm 1 \%$ as far as the semi-graphitisation stage (green-schist facies). However, compared to the known range of sedimentary kerogen $\delta^{15} \mathrm{~N}$, such an accuracy is quite good, and is particularly interesting, on one side to trace deep fluid formation (e.g. Gerling et al., 1997; Zhu et al., 2000), on the other side for the study of the Archean biosphere, as all Archean rocks of sedimentary origin have been affected at least by low grade metamorphism (e.g. Jia and Kerrich, 2004a,b). For the moment, the use of $\mathrm{CM} \delta^{15} \mathrm{~N}$ as an indicator of the initial kerogen $\delta^{15} \mathrm{~N}$ is suggested only until the semigraphitestage (i.e. low-grade metamorphic). If the contamination problems of $\mathrm{N}$-poor $\mathrm{CM}$ were solved and the $\mathrm{CM} \delta_{15} \mathrm{~N}$ steadiness through the graphitisation steps predicted by this study demonstrated, the use of CM $\delta^{15} \mathrm{~N}$ as an indicator of initial kerogen $\delta^{15} \mathrm{~N}$ could be extended to the graphitisation stage.

The investigation of nitrogen in graphite could also help to discriminate biogenic from non-biogenic fluiddeposited graphite. Much attention has been devoted to the process of metamorphic kerogen graphitization to highly crystalline graphite (Landis, 1971; Grew, 1974; Wopenka and Pasteris, 1993; Beyssac et al., 2002). Valuable information regarding the degree of metamorphism of host rocks and the nature of the carbon phases, temperatures of equilibration over a wide range of rock types among others, have been obtained based on the study of graphite (Ohmoto and Kerrick, 1977; Cesare, 1995; Barrenechea et al., 1997; Pasteris and I-Ming Chou, 1998). However, in some cases, it is not clear if graphite from in situ metamorphism of $\mathrm{CM}$ and graphite from precipitation from saturated $\mathrm{C}-\mathrm{O}-\mathrm{H}$ fluids (epigenetic or vein-type graphite) operate separately or, otherwise, if there was some kind of connection between them (Luque et al., 1998). Once identified, by combining nitrogen content and $\delta^{15} \mathrm{~N}$ with more conventional characterization parameters (crystallinity, mineralogy, $\delta_{13} \mathrm{C}$, etc.), biogenic/metamorphic graphite could be used as a geomarker for tracing Precambrian organic-rich sedimentary basins (Sreeraj et al., 2000; Dissanayake et al., 2000).

\section{Conclusions}

The present work aims to establish a methodology for undertaking the study of nitrogen isotopic evolution of carbonaceous matter during metamorphism. It was shown that, in carbonaceous-rich metasediments, nitrogen content and $\delta^{15} \mathrm{~N}$ measurements by on-line combustion are not reliable (probably because of a matrix effect inducing reactions of condensation involving nitrogen). Nitrogen content and $\delta^{15} \mathrm{~N}$ measurements were therefore performed by sealed-tube combustion. The required analytical conditions to follow the change of nitrogen content and of $\delta^{15} \mathrm{~N}$ were fulfilled in the case of anthracite to semi-graphite series. In the case of more mature samples, it was pointed out that $\mathrm{HF} / \mathrm{HCl}$ extraction of $\mathrm{CM}$ is a possible source of nitrogen contamination, so that, at the semi-graphite and graphite transition, $\mathrm{CM}$ nitrogen contents are higher estimates only and $\delta^{15} \mathrm{~N}$ analyses are meaningless. In other words, although the $\delta^{15} \mathrm{~N}$ analyses of samples with extremely high $\mathrm{C} / \mathrm{N}$ ratios $(\mathrm{N} 10,000)$ is feasible, more work 
concerning the chemical separation of carbonaceous matter from metasediments is still required before reliable $\delta^{15} \mathrm{~N}$ analyses of can be obtained.

The overall preliminary results showed that, in the case of selected homogeneous contact-metamorphic sequences, there is no significant evolution of the mean $\mathrm{CM} \delta^{15} \mathrm{~N}$ during the meta-anthracite and semi-graphite stages. The $\mathrm{CM} \delta^{15} \mathrm{~N}$ steadiness, which co-occurs with a strong nitrogen loss, can be explained assuming that the external front reaction progresses until nitrogen mineralization is complete, before progressing towards the interior part of the solid. If further field and experimental investigations prove that this model is valid, and assuming that each kerogen path brings its own isotopic signature at the metamorphism onset, where kerogen types converge, carbonaceous-rich rocks could be viewed as isotopic fossils, highly practical to investigate nitrogen from sedimentary kerogen, using metasediments. The present work brings some facts which enable us to think that the metamorphic path of the post-kerogen nitrogen would keep the memory of the initial kerogen: an interesting tool, not only to investigate the Archean biosphere, but also the nitrogen transfer from the atmosphere to the mantle through the photosynthesis sedimentation-metamorphism-subduction sequence, and to extent these studies to a cosmogeochemical approach.

\section{Acknowledgments}

This research was partially funded by a grant from Chevron Petroleum Technology Company, P.O. Box 446, La Habra, CA, U.S.A. We thank all the people who provided the samples without which this study would not have taken place: Eric Daniels (Chevron Petroleum Technology Company) and Jeffrey Levine (Consulting geologist, Tuscaloora, Alabama) for providing Pennsylvanian anthracites and for helpful discussion cites discussion, Peter Gerling (Bundesanstalt für Geowissenschaften und Rohstoffe Geozentrum Hannover) for coal samples from Northern Germany and for constructive comments. FGR graphite separates were provided by Francis Fischer (TIMCAL - Graphite and Technologies); GL samples by Zhe Zheng (Peking University, Department of Geology, Beijing, China); SB samples by Jan Jehlicka (Department of Geochemistry, Charles University, Prague, Czech Republic); PIES 6770 sample and several other coal samples from Bramsche Massif by Angelika Vieth-Redemannn (Geologishes Landesamt NRW, Krefeld Deutschland) and SG SG-K semigraphite sample by Jin Kuili (China University of Mining and Technology, Beijing, China). We also sincerelywish to thank Mark van Zuilen (Scripps
Institution of Oceanography, La Jolla) and an anonymous reviewer for

their comments and suggestions, which greatly helped improving the quality of the paper. Contribution to IPGP No. 2105. [PD]

\section{References}

Ader, M., Boudou, J.P., Javoy, M., Goffé, B., Dan Daniels, E., 1998a. Isotopic study of organic nitrogen of Westphalian anthracites from eastern Pennsylvania (USA) and from the Bramsche Massif (Germany). Org. Geochem. 29, 315-323.

Ader, M., Javoy, M., Boudou, J.P., Hieronimus, B., Roux, J., Daniels, E., 1998b. Nitrogen isotopic composition of ammonium-rich illite in anthracites and organic rich shales from Eastern Pennsylvania. Min. Mag. 62A, 13.

Ahn, J.H., Cho, M., Buseck, P.R., 1999. Interstratification of carbonaceous material within illite. Am. Mineral. 84, 1967-1970.

Akimoto, M., Ninomiya, K., Takami, S., Ishikawa, M., Sato, M., Washio, K., 2002. Hydrothermal dechlorination and denitrogenation of municipal-waste-plastics-derived fuel oil under sub- and supercritical conditions. Ind. Eng. Chem. Res. 41, 5393-5400.

Akimoto, M., Sato, T., Nagasawa, T., 2003. Hydrothermal denitrogenation of fuel oil derived from municipal waste plastics in a continuous packed-bed reactor. Ind. Eng. Chem. Res. 42, 2074-2080.

Altabet, M.A., Francois, R., 1994. Sedimentary nitrogen isotopic ratio as a recorder for surface ocean nitrate utilization. Glob. Biogeochem. Cycles 8, 103-116.

Altabet, M.A., Francois, R., Murray, D.W., Prell, W.L., 1995. Climaterelated variations in denitrification in the Arabian Sea from sediment ${ }^{15} \mathrm{~N} /{ }^{14} \mathrm{~N}$ ratios. Nature 373, 506-509.

Altabet, M.A., Higginson, M.J., Murray, D.W., 2002. The effect of millennial-scale changes in Arabian Sea denitrification on atmospheric $\mathrm{CO}_{2}$. Nature 415, 159-162.

Barrenechea, J.F., Luque, F.J., Rodas, M., Pasteris, J.D., 1997. Veintype graphite in the Jurassic volcanic rocks of the external zone of the Betic Cordillera (southern Spain). Can. Mineral. 35,1379-1390.

Beaumont, V., Robert, F., 1999. Nitrogen isotopic ratios of kerogens in Precambrian cherts: a record of the evolution of atmosphere chemistry? Precambrian Res. 96, 63-82.

Beaumont, V., Agrinier, P., Javoy, M., Robert, F., 1994. Determination of the $\mathrm{CO}$ contribution to the ${ }^{15} \mathrm{~N} /{ }^{14} \mathrm{~N}$ ratio measured by mass spectrometry. Anal. Chem. 66, 2187-2189.

Bebout, G.E., Fogel, M.L., 1992. Nitrogen-isotope compositions of metasedimentary rocks in the Catalina Schist, California: implications for metamorphic devolatilization history. Geochim. Cosmochim. Acta 56, 2839-2849.

Bennett, B., Lager, A., Russell, C.A., Gordon, D., Love, G.D., Larter, S.R., 2004. Hydropyrolysis of algae, bacteria, archaea and lake sediments; insights into the origin of nitrogen compounds in petroleum. Org. Geochem. 35, 1427-1439.

Beyssac, O., Rouzaud, J.N., Goffé, B., Brunet, F., Chopin, C., 2002. Graphitization in a high pressure, low-temperature metamorphic gradient: a Raman microspectroscopy and HRTEM study. Contrib. Mineral. Petrol. 143, 19-31.

Bonijoly, M., Oberlin, M., Oberlin, A., 1982. A possible mechanism for natural graphite formation. Int. J. Coal Geol. 1, 283-312. Boudou, J.P., Espitalié, J., 1995. Molecular nitrogen from coal pyrolysis. Kinetic modelling. Chem. Geol. 126, 319-333. 
Boudou, J.P., Mariotti, A., Oudin, J.L., 1984. Unexpected enrichment of nitrogen during the diagenetic evolution of sedimentary organic matter. Fuel 63, 1508-1510.

Boudou, J.P., Ader, M., Javoy, M., Besson, J.M., Syfosse, G., 1997. Etude expérimentale du comportement sous haute pression de l'azote organique sédimentaire. 1er Forum de Technologie des Hautes Pressions, La Londe les Maures, France.

Boyd, S.R., 1997. Determination of the ammonium content ofpotassic rocks and minerals by capacitance manometry: a prelude to the calibration of FTIR microscopes. Chem. Geol. 137, 57-66.

Boyd, S.R., 2001a. Nitrogen in the future biosphere studies. Chem. Geol. 176,1-30.

Boyd, S.R., 2001b. Ammonium as a biomarker in Precambrian metasediments. Precambrian Res. 108, 159-173.

Boyd, S.R., Hall, A., Pillinger, C.T., 1993. The measurement of $6{ }_{15} \mathrm{~N}$ in crustal rocks by static vacuum mass spectrometry: application to the origin of the ammonium in the Cornubian batholith, southwest England. Geochim. Cosmochim. Acta 57, 1339-1347.

Boyd, S.R., Réjou-Michel, A., Javoy, M., 1994. Noncryogenic purification of nanomole quantities of nitrogen gas for isotopic analysis. Anal. Chem. 66,1396-1402.

Boyd, S.R., Rejou-Michel, A., Javoy, M., 1995. Improved techniques for the extraction, purification of nanomoles quantities of nitrogen gas: the nitrogen content of diamond. Meas. Sci. Technol. 6, 297-305.

Bräuer, K., Hahne, K., 2005. Methodological aspects of the ${ }^{15} \mathrm{~N}$ analysis of Precambrian and Palaeozoic sediments rich in organic matter. Chem. Geol. 218, 361-368.

Burchill, P., Welch, L.S., 1989. Variation of nitrogen content and functionality with rank for some UK bituminous coals. Fuel 68, 100-104

Buseck, P.R., Bo-Jun, H., 1985. Conversion of carbonaceous material to graphite during metamorphism. Geochim. Cosmochim. Acta. 49 (10), 2003-2016

Busigny, V., Cartigny, C., Philippot, P., Ader, M., Javoy, M., 2003. Massive recycling of nitrogen and other fluid-mobile elements $(\mathrm{K}$, $\mathrm{Rb}, \mathrm{Cs}, \mathrm{H}$ ) in a cold slab environment: evidence from HP to UHP oceanic metasediments of the Schistes Lustrés nappe (western Alps, Europe). Earth Planet. Sci. Lett. 215, 27-42.

Busigny, V., Ader, M., Cartigny, C., 2005. Quantification and isotopic analysis of nitrogen in rocks at the ppm level using sealed-tube combustion technique. Chem. Geol. 223, 249-258.

Bustin, R.M., Ross, J.V., Rouzaud, J.N., 1995. Mechanisms of graphite formation from kerogen: experimental evidence. Int. J. Coal Geol. 28, 1-36.

Calderon-Moreno, J.M., Yoshimura, M., 2002. Non-catalytic growth of multiwall carbon nanotubes in hydrothermal fluids. Key Eng. Mater. 206-213, 2159-2162.

Caplan, M.L., Bustin, R.M., Grimm, K.A., 1996. Demise of a Devonian-Carboniferous carbonate ramp by eutrophication. Geology 24, 715-718.

Cartigny, P., De Corte, K., Shatsky, V., Ader, M., De Paepe, P., Sobolev, N., Javoy, M., 2001. The origin and formation of metamorphic microdiamonds from the Kokchetav massif, Kazakhstan: a nitrogen and carbon isotopic study. Chem. Geol. 176, 265 281.

Cesare, B., 1995. Graphite precipitation in C-O-H fluid inclusions: closed system compositional and density changes, and thermobarometric implications. Contrib. Mineral. Petrol. 122, 25-33.

Daniels, E.J., Altaner, S.P., 1990. Clay mineral authigenesis in coal and shale from the Anthracite region, Pennsylvania. Am. Mineral. 75, 825-839.

Daniels, E.J., Altaner, S.P.,1993. Inorganic nitrogen in anthracite from eastern Pennsylvania, U.S.A. Int. J. Coal Geol. 22, 21-35. Daulan, C., Lyubchik, S.B., Rouzaud, J.N., Béguin, F., 1998. Influence of anthracite pretreatment in the preparation of activated carbons. Fuel 77, 495-502.

Dissanayake, C.B., Chandrajith, R., Boudou, J.P., 2000. Graphite as a geomarker - application to continental reconstruction of panAfrican Gondwana terrains. Gondwana Res. 3, 405 413.

Durand, B., Monin, J.C., 1980. Elemental analysis of kerogens (C,H, O,N,S,Fe). In: Durand, B. (Ed.), Kerogen. Edition Technip, Paris, pp. 113-142.

Durand, B., Nicaise, G., 1980. Procedures for kerogen isolation. In: Durand, B. (Ed.), Kerogen. Edition Technip, Paris, pp. 35-53. Everlien, G., 1997. Hydrous pyrolysis of high-maturity Palaeozoic coals and Black Shales from Central Europe and adjacent areas thermodynamic considerations. Geol. Jahrb. D103, 43-64.

Fryer, J.R., 1981. The micropore structure of disordered carbons determined by high resolution electron microscopy. Carbon 19 431-439.

Ganeshram, R.S., Pedersen, T.F., Calvert, S.E., Francois, R., 2002. Reduced nitrogen fixation in the glacial ocean inferred from changes in marine nitrogen and phosphorus inventories. Nature 415,156-159.

Gerling, P., Idiz, E., Everlien, G., Sohns, E., 1997. New aspects on the origin of nitrogen in natural gas in northern Germany. Geol. Jahrb. D103,65-84.

Gilmour, I., Pillinger, C.T., 1985. Stable carbon isotopic analysis of sedimentary organic matter by stepped combustion. Org. Geochem. 8, 421-426.

Grew, E.S., 1974. Carbonaceous material in some metamorphic rocks of New England and other areas. J. Geol. 82, SO-73.

Haendel, D., Mühle, K., Nitzsche, H., Stiehl, G., Wand, U., 1986. Isotopic variations of the fixed nitrogen in metamorphic rocks. Geochim. Cosmochim. Acta 50, 749-758.

Holmes, M.E., Schneider, R.R., Müller, P.J., Segl, M., Wefer, G., 1997. Reconstruction of past nutrient utilization in the eastern Angola basin based on sedimentary ${ }^{15} \mathrm{~N} /{ }^{14} \mathrm{~N}$ ratios. Palaeoceanography 12 , 604-614.

Hower, J.C., Gayer, R.A., 2002. Mechanisms of coal metamorphism: case studies from Paleozoic coalfields. Int. J. Coal Geol. 50, 215 245 .

Hryckowian, E., Dutcher, R.R., Dachille, F., 1967. Experimental studies of anthracite coals at high pressures and temperatures. Econ. Geol. 62, 517-539.

Jakobsson, S., Oskarsson, N., 1994. The system C-O in equilibrium with graphite at high pressure and temperature: an experimental study. Geochim. Cosmochim. Acta 58, 9-17.

Javoy, M., Pineau, F., Demaiffe, D., 1984. Nitrogen and carbon isotopic composition in the diamonds of Mbuji Mayi (Zaïre). Earth Planet. Sci. Lett. 68, 399-412.

Jedwab, J., Boulegue, J., 1984. Graphite crystals in hydrothermal vents. Nature $310,41-43$.

Jehlicka, J., 1994. Etude structurale de matières organiques soumises a des processus métamorphiques. Techniques et Méthodes, vol. 238 Editions BRGM Orléans, France. 230 pp.

Jehlicka, J., Bény, C., Rouzaud, J.N., 1997. Raman microspectrometry of accumulated non-graphitized solid bitumens. J. Raman Spectrosc. 28, 717-724.

Jehlicka, J., Svatos, A., Frank, O., Uhlik, F., 2003. Evidence for fullerenes in solid bitumen from pillow lavas of Proterozoic age from Mitov (Bohemian Massif, Czech Republic). Geochim. Cosmochim. Acta 67, 1495-1506. 
Jia, Y., Kerrich, R., 2004a. A reinterpretation of the crustal N-isotope record: evidence for a ${ }^{15} \mathrm{~N}$-enriched Archean atmosphere? Terra Nova 16, 102-108.

Jia, Y., Kerrich, R., 2004b. Nitrogen 15-enriched Precambrian kerogen and hydrothermal systems. Geochem. Geophy. Geosyst. 5 (number 7).

Juster, T.C., Brown, P.E., Bailey, S.W., 1987. NH4-bearing illite in very low grade metamorphic rocks associated with coal, northeastern Pennsylvania. Am. Mineral. 72, 555-565.

Katritzky, A.R., Shipkova, P.A., Allin, S.M., Barcock, R.A., Siskin, M., Olmstead, N., 1995. Aqueous high-temperature chemistry. 22. Nitrogen-containing heterocycles in supercritical water at $460{ }^{\circ} \mathrm{C}$. Energy Fuels 9, 580-589.

Kelemen, S.R., Freund, H., Gorbaty, M.L., Kwiatek, P.J., 1999. Thermal chemistry of nitrogen in kerogen and low rank coal. Energy Fuels 13, 529-538.

Kelemen, S.R., Afeworki, M., Gorbaty, M.L., Kwiatek, P.J., 2002. XPS and $15 \mathrm{~N}$ NMR study of nitrogen forms in carbonaceous solids. Energy Fuels 16, 1507-1515.

Kendall, C., Grim, E., 1990. Combustion tube method for measurement of nitrogen isotope ratios using calcium oxide for total removal of carbon dioxide and water. Anal. Chem. 62, 526-529.

Kerridge, J.F., Chang, S., Shipp, R., 1987. Isotopic characterization of kerogen-like material in the Murchison carbonaceous chondrite. Geochim. Cosmochim. Acta. 51, 2527-2540.

Kim, J.H., 1986. Structures of the Ojeongsan area, Moongyeong coal field, South Korea. J. Geol. Soc. Korea 22, 135-145.

Knicker, H., Hatcher, P.G., Scaroni, A.W., 1996. A solid solid-state ${ }_{15} \mathrm{~N}$ NMR spectroscopic investigation of the origin of nitrogen structures in coal. Int. J. Coal Geol. 32, 255-278.

Kraft, T., Nickel, K.G., 2000. Carbon formed by hydrothermal treatment of a-SiC crystals. J. Mater. Chem. 10, 671-680.

Kwiecifiska, B., Petersen, H.I., 2004. Graphite, semi-graphite, natural coke, and natural char classification-ICCP system. Int. J. Coal Geol. 57 (2), 99-116.

Landis, C.A., 1971. Graphitization of dispersed carbonaceous material in metamorphic rocks. Contrib. Mineral. Petrol. 30, 34-45. Levine, J.F., Davis, A., 1989. Reflectance anisotropy of Upper Carboniferous coals in the Appalachian foreland basin, Pennsylvania, USA. Int. J. Coal Geol. 13, 341-373.

Lewan, M.D., 1997. Experiments on the role of water in petroleum formation. Geochim. Cosmochim. Acta 61, 3691-3723.

Libera, J., Gogotsi, Y., 2001. Hydrothermal synthesis of graphite tubes using Ni catalyst. Carbon 39, 1307-1318.

Luque, F.J., Pasteris, J.D., Wopenka, B., Rodas, M., Barrenechea, J.F., 1998. Natural fluid-deposited graphite: mineralogical characteristics and mechanisms of formation. Am. J. Sci. 298, 471-498. Mahajan, O.P., 1984. Physical characterization of coal. Powder Technol. 40, 1-15.

Mastalerz, M., Schimmelmann, A., 2002. Isotopically exchangeable organic hydrogen in coal relates to thermal maturity and maceral composition. Org. Geochem. 33, 921-931.

Mingram, B., Bräuer, K., 2001. Ammonium concentration and nitrogen isotope composition in metasedimentary rocks from different tectonometamorphic units of the European Variscan Belt. Geochim. Cosmochim. Acta 65, 273-287.

Nakano, S., Akaishi, M., Sasaki, T., 2001. Influence of water agent on high-pressure/high-temperature transformation of graphitic $\mathrm{BC}_{2} \mathrm{~N}$. Chem. Mater. 13, 350-354.

Nover, G., Stoll, J.B., von der Gönna, J., 2005. Promotion of graphite formation by tectonic stress - a laboratory experiment. Geophys. J. Int. 160, 1059-1067.

Oberlin, M., 1984. Carbonization and graphitization. Carbon 22, 521-
541.

Oberlin, A., Terrière, G., 1975. Graphitization studies of anthracites by high resolution electron microscopy. Carbon 13, 367-376.

Oh, J.H., Rouzaud, J.N., Oberlin, A., Deurbergue, A., Kwak, Y.H., 1991. Structural study of graphitization in the Moongyeong coalfield, South Korea. Bull. Soc. Géol. Fr. 162, 399-407.

Ohmoto, H., Kerrick, D., 1977. Devolatilisation equilibria in graphitic systems. Am. J. Sci. 277, 1013-1044.

Pan, L.S., Andersen, T.N., Eyring, H., 1966. Experimental study of the effects of temperature and ultra-high pressure on the coalification of bituminous coal. Ind. Eng. Chem. Process Des. Dev. 5, 242246.

Papineau, D., Mojzsis, S.J., Karhu, J.A., Marty, B., 2005. Nitrogen isotopic composition of ammoniated phyllosilicates: case studies from Precambrian metamorphosed sedimentary rocks. Chem. Geol. 216, 37-58.

Parwel, A., Ryhage, R., Wickman, F.E., 1957. Natural variations in the relative abundances of the nitrogen isotopes. Geochim. Cosmochim. Acta 11, 165-170.

Pasteris, J.D., I-Ming Chou, I.M., 1998. Fluid-deposited graphitic inclusions in quartz: comparison between KTB (German Continental Deep-Drilling) core samples and artificially reequilibrated natural inclusions. Geochim. Cosmochim. Acta 62, 109-122.

Peters, K.E., Sweeney, R.E., Kaplan, I.R., 1978. Correlation of carbon and nitrogen stable isotope ratios in sedimentary organic matter. Limnol. Oceanogr. 23, 598-604.

Price, L.C., Dewitt, E., 2001. Evidence and characteristics of hydrolytic disproportionation of organic matter during metasomatic processes. Geochim. Cosmochim. Acta 65, 3791-3826.

Radlinski, A.P., Mastalerz, M., Hinde, A.L., Hainbuchner, M., Rauch, H., Baron, M., Lin, J.S., Fan, L., Thiyagarajan, P., 2004. Application of SAXS and SANS in evaluation of porosity, pore size distribution and surface area of coal. Int. J. Coal Geol. 59, 245271.

Rau, G.H., Arthur, M.A., Dean, WE., 1987. ${ }^{15} \mathrm{~N} /{ }^{14} \mathrm{~N}$ variations in Cretaceous Atlantic sedimentary sequences: implication for past changes in marine nitrogen biochemistry. Earth Planet. Sci. Lett. 82,269-279.

Rigby, D., Batts, B.D., 1986. The isotopic composition of nitrogen in Australian coals and oil shales. Chem. Geol. 58, 273-282.

Rouzaud, J.N., Oberlin, A., 1990. The characterization of coals and cokes by transmission electron microscopy. In: Charcosset, $\mathrm{H}$. (Ed.), New Methodologies in Coal Characterization. Elsevier, Amsterdam, p. 311.

Schimmelmann, A., Boudou, J.P., Lewan, M.D., Wintsch, R.P., 2001. Experimental controls on $\mathrm{D} / \mathrm{H}$ and ${ }^{13 \mathrm{C} / 12 \mathrm{C}}$ ratios of kerogen, bitumen and oil during hydrous pyrolysis. Org. Geochem. 32, 1009-1018.

Schubert, C.J., Calvert, S.E., 2001. Nitrogen and carbon isotopic composition of marine and terrestrial organic matter in Arctic Ocean sediments: implications for nutrient utilization and organic matter composition. Deep-Sea Res. I48, 789-810.

Schwab, V., Spangenberg, J.E., Grimalt, J.O., 2005. Chemical and carbon isotopic evolution of hydrocarbons during prograde metamorphism from $100{ }^{\circ} \mathrm{C}$ to $550{ }^{\circ} \mathrm{C}$ : case study in the Liassic black shale formation of Central Swiss Alps. Geochim. Cosmochim. Acta 69, 1825-1840.

Sephton, M.A., Verchovsky, A.B., Bland, P.A., Gilmour, I.I., Grady, M.M., Wright, I.P., 2003. Investigating the variations in carbon and nitrogen isotopes in carbonaceous chondrites. Geochim. Cosmochim. Acta 67, 2093-2108. 
Sreeraj, K., Wada, H., Santosh, M., 2000. Graphite as geomarker and fluid index in east Gondwana terrains. Gondwana Res. 3, 560-561.

Stanczyk, K., Boudou, J.P., 1994. Elimination of nitrogen from coal in pyrolysis and hydropyrolysis - a study of coal and model chars. Fuel 73, 940-944.

Sucha, V., Kraus, I., Madejova, J., 1994. Ammonium illite from anchimetamorphic shales associated with anthracite in the Zemplinicum of the western Carpathians. Clay Miner. 29, 369-377.

Suchy, V., Frey, M., Wolf, M., 1997. Vitrinite reflectance and shearinduced graphitization in erogenic belts: a case study from the Kandersteg area, Helvetic Alps, Switzerland. Int. J. Coal Geol. 34, 120

Tagiri, M., Oba, T., 1986. Hydrothermal syntheses of graphite from bituminous coal at 0.5-5 kbar water vapour pressure and 300$600{ }^{\circ}$ C. J. Jpn. Assoc. Mineral., Petrol. Econ. Geol. 81, 260-271.

Talbot, M., Johannesseen, T., 1992. A high resolution palaeoclimatic record for the last solution 27,500 years in tropical West Africa from the carbon and nitrogen isotopic composition of lacustrine organic matter. Earth Planet. Sci. Lett. 110, 23-37.

Teagle, D.A.H., Kerrich, T.R., Craw, D., Brewer, T.S., 2005. The behavior of nitrogen and nitrogen isotopes during metamorphism and mineralization: evidence from the Otago and Alpine Schists, New Zealand. Earth Planet. Sci. Lett. 233, 229-246.

Ueno, Y., Yoshioka, H., Maruyama, S., Isozaki, Y., 2004. Carbon isotopes and petrography of kerogens in 3.5-Ga hydrothermal silica dikes in the North Pole area, Western Australia. Geochim. Cosmochim. Acta 68, 573-589.

Van Krevelen, D.W., 1961. Coal. Elsevier, Amsterdam.

Van Krevelen, D.W., 1990. Properties of Polymer: Their Correlation with Chemical Structure; Lymer: Their Estimation and Prediction from Additive Group Contribution, 3rd ed. Elsevier, Amsterdam.
Van Zuilen, M.A., Mathew, K., Wopenka, B., Lepland, A., Marti, K., Arrhenius, G., 2005. Nitrogen and argon isotopic signatures in graphite from the 3.8-Ga-old Isua Supracrustal Belt, Southern West Greenland. Geochim. Cosmochim. Acta 69, 1241-1252.

Volkova, I.B., Bogdanova, M.V., 1989. Properties of high-rank coals and dispersed organic matter of associated rocks in the Donets Basin (U.S.S.R.). Int. J. Coal Geol. 11, 315-339.

Whiticar, M.J., 1996. Stable isotopes geochemistry of coals, humic kerogens and related natural gases. Int. J. Coal Geol. 32, 191-215.

Williams, L.B., Ferrell Jr., R.E., Hutcheon, I., Bakel, A.J., Walsh, M.M., Krouse, H.R., 1995. Nitrogen isotope geochemistry of organic matter and minerals during diagenesis and hydrocarbon migration. Geochim. Cosmochim. Acta 59, 765-779.

Wojtowicz, M.A., Pels, J.R., Moulijn, J.A., 1995. The fate of nitrogen functionalities in coal during pyrolysis and combustion. Fuel 74, 507-516

Wopenka, B., Pasteris, J.D., 1993. Structural characterization of kerogens to granulite-facies graphite: applicability of Raman microprobe spectroscopy. Am. Mineral. 78, 533-557.

Xiao, B., Boudou, J.P., Thomas, K.M., 2005. Reactions of nitrogen and oxygen surface groups in nanoporous carbons under inert and reducing atmospheres. Langmuir 21, 3400-3409.

Zheng, Z., Chen, X., 1995. Raman spectra of coal-based graphite. Sci. China, Ser B Chem. Life Sci. Earth Sci. 38, 97-106.

Zheng, Z., Zhang, J., Huang, J.Y., 1996. Observations of microstructure and reflectivity of coal graphites for two locations in China. Int. J. Coal Geol. 30, 277-284.

Zhu, Y., Shi, B., Fang, C., 2000. The isotopic compositions of molecular nitrogen: implications on their origins in natural gas accumulations. Chem. Geol. 164, 321-330.

Zolotov, M.Y., Shock, E.L., 2001. Stability of condensed hydrocarbons in the solar nebula. Icarus 150, 323-337. 